\title{
p53-based Cancer Therapy
}

\author{
David P. Lane ${ }^{1}$, Chit Fang Cheok ${ }^{1}$, and Sonia Lain ${ }^{2}$ \\ 1p53 Laboratory (A-Star) 8A Biomedical Grove Immunos Singapore 138648 \\ ${ }^{2}$ Department of Microbiology, Tumor and Cell biology, Karolinska Institutet Stockholm SE-171 77 Sweden \\ Correspondence: dplane@p53lab.a-star.edu.sg
}

\begin{abstract}
Inactivation of p53 functions is an almost universal feature of human cancer cells. This has spurred a tremendous effort to develop p53 based cancer therapies. Gene therapy using wild-type p53, delivered by adenovirus vectors, is now in widespread use in China. Other biologic approaches include the development of oncolytic viruses designed to replicate and kill only p53 defective cells and also the development of siRNA and antisense RNA's that activate $\mathrm{p} 53$ by inhibiting the function of the negative regulators $\mathrm{Mdm} 2, \mathrm{MdmX}$, and HPV E6. The altered processing of p53 that occurs in tumor cells can elicit T-cell and B-cell responses to p53 that could be effective in eliminating cancer cells and p53 based vaccines are now in clinical trial. A number of small molecules that directly or indirectly activate the p53 response have also reached the clinic, of which the most advanced are the p53 mdm2 interaction inhibitors. Increased understanding of the p53 response is also allowing the development of powerful drug combinations that may increase the selectivity and safety of chemotherapy, by selective protection of normal cells and tissues.
\end{abstract}

$\mathrm{T}_{\mathrm{a}}^{\mathrm{h}}$ hirty years of research on $\mathrm{p} 53$ have produced a detailed understanding of its structure and function. The almost universal loss of p53 activity in tumors has spurred an enormous effort to develop new cancer treatments based on this fact. Sophisticated animal models have shown that activation of the p53 response in even advanced tumors can be curative (Martins et al. 2006; Ventura et al. 2007; Xue et al. 2007). The p53 gene therapy, Gendicine, is approved in China and its US counterpart, Advexin, has shown activity in number of clinical trials. The $\mathrm{p} 53$ protein level is raised in many tumors by virtue of an increase in the protein's half life and this tumor specific alteration in p53 processing has attracted tumor immunologists, who are now testing a number of p53 based vaccines in cancer patients (Speetjens et al. 2009).

In more conventional approaches a range of small druglike molecules targeting the p53 system have been developed and several are now in clinical trials. Of critical importance has been the development of small-molecule inhibitors of the p53-Mdm2 protein interaction such as the Nutlins (Vassilev et al. 2004), which have shown activity against human xenografts in preclinical models. Advanced structural approaches have provided compelling support for the idea that some mutant p53 proteins can be targets for small molecules that would

Editors: Arnold J. Levine and David P. Lane

Additional Perspectives on The p53 Family available at www.cshperspectives.org

Copyright (C) 2010 Cold Spring Harbor Laboratory Press; all rights reserved; doi: 10.1101/cshperspect.a001222

Cite this article as Cold Spring Harb Perspect Biol 2010;2:a001222 
cause them to regain wild-type function (Joerger et al. 2006). Cell based screening methods have identified small molecules that can activate both mutant and wild-type p53 proteins in tumor cells to induce apoptosis. These screens, and RNAi based approaches, have revealed many new targets for therapy in the p53 pathway. In an exciting new approach, that has been validated in other tumor suppressor pathways, the search is on for targets in pathways that will show synthetic lethal interactions with loss of p53 function. Finally drug combinations have been developed that can selectively kill cancer cells that lack p53 function while protecting normal cells (Sur et al. 2009). The next few years hold out the prospect of new p53 based therapies that will be of wide application in cancer and other diseases.

\section{GENE THERAPY BASED APPROACHES}

Transfection of the wild-type p53 gene into a variety of human tumor cells was shown in the late 1980s and early 1990s to induce apoptosis and growth inhibition. In murine model systems, in which p53 function is reactivated specifically within the tumor, a curative response is seen. This established that even advanced tumors retained an ability to be inhibited by p53. Interestingly, when such approaches were carried out in lymphoma models the activity of p53 that induced a antitumor activity was seen to be apoptosis (Ventura et al. 2007) whereas in a liver tumor model the p53 activity induced a senescent phenotype. This, in a dramatic study, was shown to then induce an intense macrophage response that cleared the tumor (Xue et al. 2007). Repeatedly in this article we will return to these themes. What response does $\mathrm{p} 53$ activation produce in normal tissues as compared to tumor cells and what modulates and controls these differences?

Jack Roth was the first to attempt p53 gene therapy in man. In 1996 he used direct injection of a retroviral vector expressing human p53 under the control of an actin promoter to treat non-small cell lung carcinoma (NSCLC) (Roth et al. 1996). Later studies identified adenovirus vectors expressing human full length wild-type p53 as suitable for large scale GMP production at economic cost. These viruses are engineered to lack certain early proteins and are thus replication defective. They can however be grown to high titer in special stable human cell lines, such as the 293 and PER. C6 cells, which have been engineered to stably express these early viral proteins in trans. In vitro studies showed that such viruses could infect and inhibit the growth of many different human tumor cells and proved effective in a variety of xenograft models. Remarkably such viruses did not seem to induce apoptosis or senescence in normal tissues or cells. Thus p53 gene therapy has an excellent safety profile. In p53 based reporter systems adenoviral infection, per se, unlike transfection (Renzing and Lane 1995), does not induce a p53 response. An advantage of the adenovirus delivery system is that it does not result in integration of the vector DNA into the host cell, unlike retrovirus based systems that have proved to be oncogenic in man. The virus effectively results in a burst of p53 production in the infected cell and remarkably normal cells can recover from this process. In many tumor cells however an irreversible induction of apoptosis takes place. The obvious problems with this approach are the inability to infect every cell in the tumor with virus and problems of effective systemic or repeated dosing because of the presence of a host antibody to Adenoviruses that reduce their infectivity. Supporters of the approach suggest that p53 induction can induce powerful bystander and immunologic responses that can overcome the inability to infect every cell and that, although neutralizing antibodies can reduce infectivity, this is not as big a problem as anticipated when measured in the clinic. Using this initial approach many thousands of patients have received p53-based gene therapies in clinical trials mostly in the USA and in China. Although some remarkable clinical cases have been reported Advexin has not yet won approval from the FDA and very recently the company developing it was closed (Senzer et al. 2007). However in China the use of adenovirus gene therapy for the treatment of head and neck cancer in combination with radiation was approved in 2003 and the product "Gendicine" has been 
marketed for the last 7 years. The case of p53 gene therapy is of considerable international interest because here we have what could be argued is a highly sophisticated "western" medicine approved in China but not in the USA. The analysis of 2500 patients treated by Gendicine has been published and the production facilities and filings of the company are to a very high international standard (Shi and Zheng 2009). In a final, provocative, twist Shenzen Si Biono GenTech has now opened an FDA approved trial in the USA. Although the anticipated difficulties about systemic delivery and immune responses to the virus are easy to imagine, it is important to recognize that improvements in functional imaging and local delivery devices may open up many fresh possibilities for this type of medicine. It may be of especial value where lesions occur in inoperable sites (Tian et al. 2009). At the moment the p53 gene delivered is wild type in sequence, but the design of "super" p53s for gene therapy is well advanced (Fig. 1). Given the temporary period of p53 protein expression that follows Adenovirus infection, improvements in the stability of the protein achieved by engineering out the $\mathrm{Mdm} 2$ binding regulation and enhancing the thermodynamic stability of the DNA binding core can be envisioned. In another enhancement, alterations in the sequence of the p53 protein that favor the induction of apoptotic genes (Saller et al. 1999) and perhaps genes with bystander activity have been discovered. Alterations in the oligomerization domain to avoid dominant negative inhibition by endogenous mutant $\mathrm{p} 53$ proteins have been developed. Early reports suggested that creating a fusion protein between p53 and the HSV protein VP22 could allow the produced protein to spread from cell to cell (Phelan et al. 1998). In another aspect changes to the virus coat proteins can be made to improve delivery by engineering in new receptors for tumor target proteins onto the viral surface and engineering out the most dominant epitopes recognized by the host immune response before adenovirus infection (Ulasov et al. 2007).

\section{ADENOVIRUS BASED THERAPY ONYX 015}

In an attempt to exploit loss of p53 function in human tumors to develop selective medicines Frank McCormick and his colleagues came up with the brilliant concept of designing a virus that could only replicate in p53 negative cells (Bischoff et al. 1996). Exploiting a virus with a known deletion in the E1B region of its genome the Onyx company developed and brought into clinical trial the oncolytic Onyx $\mathrm{O} 15$ virus. The early trials showed promise and this virus

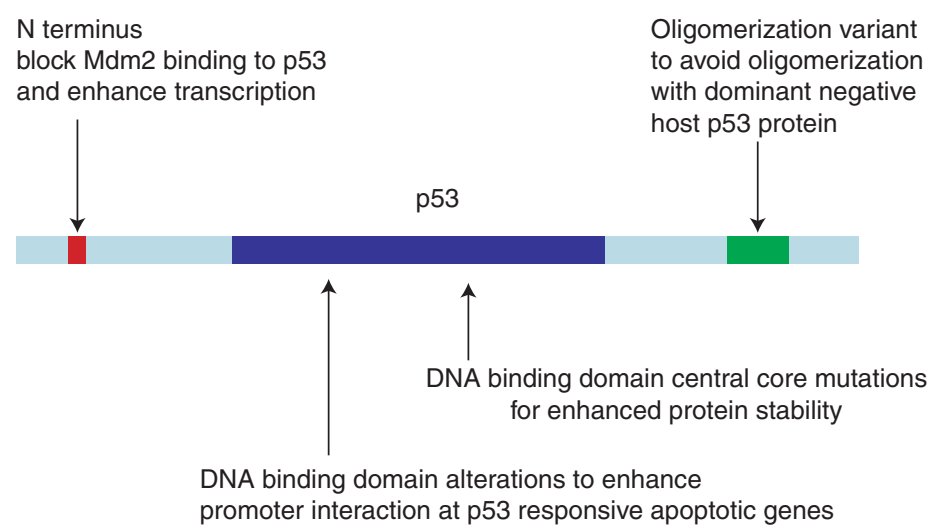

Figure 1. Design considerations of a superactive p53 for gene therapy. The p53 protein can be modified to be more potent and effective in gene therapy. At the amino terminus the F19A mutant makes p53 resistant to Mdm2 mediated degradation. Other mutations in this region may enhance its activity as a transcription factor. In the DNA binding domain the $121 \mathrm{~F}$ mutation makes the protein better at inducing apoptosis rather than growth arrest. 
has now been licensed to Shenzhen Si Biono. The concept of such tumor restricted viruses has the potential to overcome many of the perceived difficulties of the replication defective viruses because it should, after systemic delivery, proliferate only in tumor cells and not in normal cells. Although the initial tests with Onyx 015 suggested that the early region deletion allowed it's effective replication in, and killing of, p53 mutant but not p53 wild-type cells, subsequent studies proved these results to be an oversimplification. In the current view the host range of the defective virus seems to be defined not purely by p53 status but rather by the state of the stress response in the target cell. Tumor cells that are permissive for Onyx 015 replication are able to export late viral mRNA in the absence of viral early proteins (O'Shea et al. 2004). This appears to be a constitutive stress response and can be mimicked by heat shock (O'Shea et al. 2005). The concept of selectively oncolytic viruses has now been greatly developed (Bazan-Peregrino et al. 2008).

\section{ANTISENSE AND SIRNA APPROACHES}

In those tumors where p53 is wild type but is not active because of the expression of negative regulatory proteins, siRNA can be used to activate the p53 response. Two negative regulators have received most attention in this regard. In the case of tumors associated with the expression of human papilloma viruses such as cervical, anogential, and head and neck cancers, the inactivation of the viral E6 protein is a rational target. HPV E6 binds to and targets p53 for inactivation and degradation by the Hect domain E3 ligase E6AP. The introduction of siRNA to E6 induces a rapid and effective p53 response (Jiang and Milner 2002). As with gene therapy the challenge is effective delivery but certainly in some anatomical sites, like the eye, RNA-based therapies are attractive. In tumors where p53 is wild type but inactivated by the Mdm2 E3 ligase (discussed in more detail later) then siRNA to Mdm2 can be highly effective (Yu et al. 2006; Zhang et al. 2005).

\section{p53 VACCINES}

The host immune response can be extraordinarily effective in controlling tumor growth. In model systems using virally transformed cells, small numbers of cytotoxic $\mathrm{T}$ cells that recognize peptides derived from the viral transforming antigen, displayed on the surface of the tumor cell through the MHC system, can completely control tumor growth. The remarkable growth of virally transformed tumors in human patients on long term immuno-suppression provide dramatic proof of the physiological importance of these processes in man (Shamanin et al. 1996). Why then is tumor immunity not apparently more effective against spontaneously arising tumors in man? The most obvious explanation is the absence of appropriate tumor specific antigens. It is vitally important that the immune system distinguish self from nonself so that the system is essentially "tolerant" or nonreactive to self antigens. This is achieved by the filtering out during their differentiation process of $\mathrm{T}$ cells bearing receptors that can recognize "self" and through the action of regulatory $\mathrm{T}$ cells in the periphery. It is in this context that the excitement about the p53 system as a potential route to tumor vaccination has arisen (DeLeo 1998). This is because the p53 that is present in tumor cells may be considered "nonself" or tumor specific (Lauwen et al. 2008). The causes of this tumor specificity can be seen to be of two types. Firstly the tumor specific mutations present in the p53 protein may alter its antigenicity, if the mutations occur in a region of the protein that can be presented as an epitope to the $\mathrm{T}$ cell. Second, and potentially more exciting because of its universal nature, the p53 protein in tumor cells accumulates to high levels implying that it is subject to different processes of degradation, which in turn may lead to the production of different peptide fragments to those that result from the processing of $\mathrm{p} 53$ in normal tissue cells. These changes in processing are caused by inhibition of $\mathrm{Mdm} 2$ activity, altered folding patterns and chaperone complexes (Muller et al. 2008). Increased understanding of immune function, of immunological tolerance, of antigen processing and the 
availability of powerful immune modulating drugs and antibodies are leading to a renaissance in tumor immunology. Currently a variety of p53-based vaccines have proved effective in animal models and are now undergoing trial in man. Key p53 peptide epitopes have been discovered (Hoffmann et al. 2002; Sakakura et al. 2007) and the major problem has emerged as one of steering the T-cell response toward effective tumor rejection rather than tolerance. In this context it is provocative to think about how drugs that modulate $\mathrm{p} 53$ processing may enhance or inhibit such T-cell responses. It is also noteworthy that as the use of conventional cytotoxic therapies is replaced by less immunosuppressive treatment regimes immunotherapy may be able to play a larger role in cancer care.

\section{SMALL MOLECULE APPROACHES TO p53-BASED THERAPY}

The detailed analysis of the p53 pathway that has taken place in the last decade has allowed the detailed description and validation of a number of targets suitable for drug discovery that are allowing pharmaceutical control the p53 pathway (Fig. 2). For the treatment of cancers that retain wild-type p53 a number of nongenotoxic molecules have been identified that can activate p53 and induce tumor cell death. These molecules might be expected to induce p53 in normal tissues as well and their therapeutic index therefore depends on differences in the nature of the cellular and tissue response to p53 induction in tumors versus normal tissues. The most advanced of these molecules are those that act by blocking the p53 Mdm2 interaction or otherwise inactivate $\mathrm{Mdm} 2$ function and three of these molecules are now in clinical trial.

In targeting those tumors that express a mutant $\mathrm{p} 53$ protein, specific approaches have been taken using both phenotypic and biochemical screens to identify molecules that can restore mutant p53 activity (Bykov et al. 2002). One such molecule PRIMA-1 ${ }^{\text {MET }}$ is now in clinical trial. Though its mechanism of action is still subject to discussion, its preclinical efficacy in

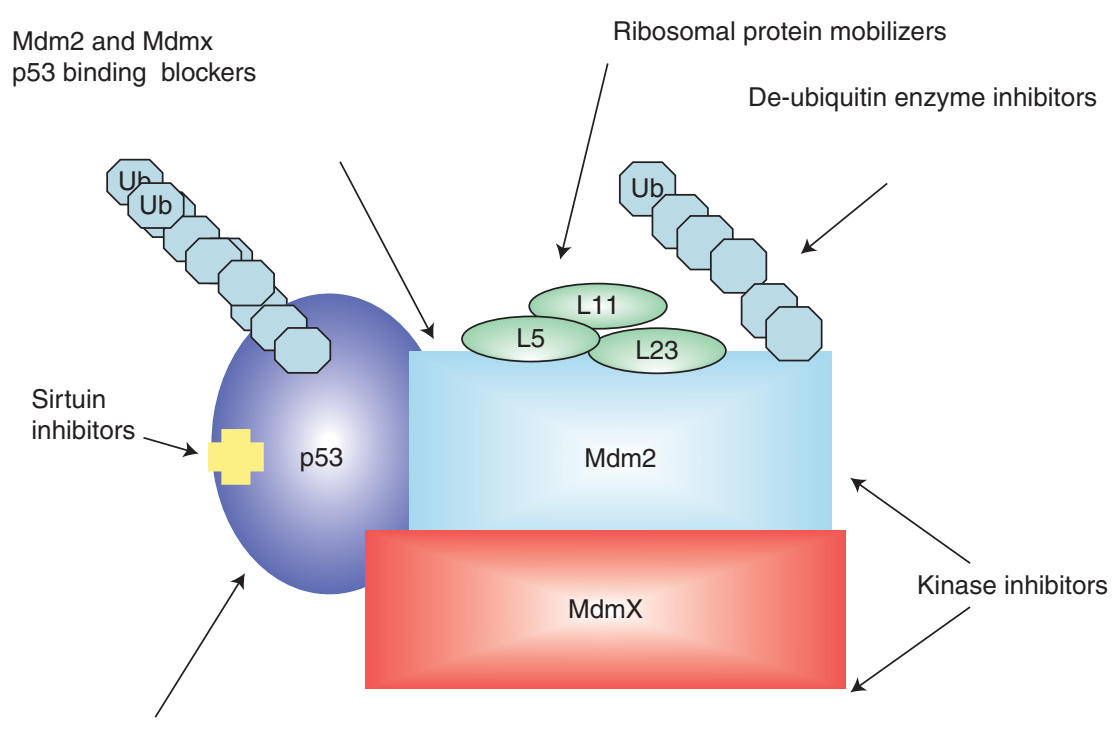

Nuclear export inhibitors

Figure 2. Targets for small molecules to activate the p53 response. Small molecules that can activate the p53 response include those that block interaction with $\mathrm{Mdm} 2$ or $\mathrm{MdmX}$, as shown above, Inhibit proteins that deacetylate p53 such as the sirtuins, Kinase inhibitors such as Roscovitine, molecules that block deubiquitinating enzymes and molecules that mobilize ribosomal proteins. 
xenograft models was such that it clearly justified examining this molecule for clinical activity.

An exciting concept that has recently achieved dazzling clinical success is that of synthetic lethality. In the most advanced example of this approach tumors that lack DNA repair function by virtue of loss of expression of functional BRCA1 or BRCA2 proteins have been found to be extraordinarily sensitive to killing by the inhibition of the PARP enzyme (Farmer et al. 2005). These results have galvanized the p53 community to seek drugs that act on the same principle. Screens are thus in place using both small molecule libraries and RNAi methods to try to determine which cellular pathways might have a synthetic lethal relationship with p53. In a refinement of this approach combinations of small molecules have been developed that can selectively kill p53 mutant tumor cells using the concept of cyclotherapy. In this approach two drugs are used in combination to treat p53 mutant tumors. The first drug, a nongenotoxic p53 inducer is used to induce a reversible cell cycle arrest in normal proliferative tissues (Carvajal et al. 2005; Kranz and Dobbelstein 2006). The second drug is designed to kill only proliferating cells and is thus able to now kill only the p53 mutant tumor cells but not the normal proliferating tissues. Such approaches would reduce the side effects such as neutropenia (Sur et al. 2009), hair loss, immune suppression, and mucositis that are seen with many cyctotoxic chemotherapies. In the remainder of this article these different smallmolecule approaches are discussed.

\section{INHIBITORS OF THE p53 Mdm2 INTERACTION}

The Mdm2 protein was discovered in 1987 (Cahilly-Snyder et al. 1987) as the protein product of a gene that was amplified on a double minute chromosome in some transformed mouse cells. In 1992 Levine and his colleagues discovered that the protein could bind tightly to p53 and inhibit its activity as a transcription factor (Momand et al. 1992) and they subsequently showed it was part of an autoregulatory loop because the $\mathrm{Mdm} 2$ gene contained a p53 binding site and $\mathrm{Mdm} 2$ gene transcription could be induced by p53 (Barak et al. 1993; Wu et al. 1993). Although initial mapping studies localized the interaction between p53 and Mdm2 to the amino termini of both proteins (Chen et al. 1993) it was studies using synthetic peptides and X-Ray crystallography that first suggested that the interaction between p53 and Mdm2 might be "druggable." In 1994 Picksley et al. (Picksley et al. 1994) showed that a peptides as short as six amino acids (TFSDLW in human p53, TFSGLW in murine p53 ) derived from the amino terminus of p53 could bind to Mdm2. This work was brought forward by two land mark studies in 1996. In one study the $\mathrm{X}$ ray structure of $\mathrm{Mdm} 2$ bound to a p53 derived peptide was solved at high resolution (Kussie et al. 1996) and in a second study phage display and peptide libraries were used to establish fine details of the specificity of the Mdm2 p53 interaction (Bottger et al. 1996). The agreement between these independent studies was remarkable, identifying the p53 interaction as being dependant on the formation of a short helical structure in p53 that bound into a deep hydrophobic pocket in Mdm2. Three amino acids were seen to be of critical importance in forming the interaction: F19, W23, and L26. Since those early studies immense progress has been made in the study of this interaction with a number of highly potent peptides now co-crystallized with $\mathrm{Mdm} 2$, allowing effective protein dynamic modeling of the interface allowing peptides that bind up to 2000 times more avidly to $\mathrm{mdm} 2$ than the original peptide to be developed (Fig. 3). This progress has raised two critical issues. The first is, can these peptidic molecules be converted in to drugs and the second is, is an inhibitor of the p $53 \mathrm{Mdm} 2$ interaction likely to be a successful therapeutic. Two approaches have been taken to developing Mdm2 interaction inhibitors, in the case of Verdine and colleagues p53 interacting peptides have been stabilized by introducing additional chemical cross links. This exciting approach called peptide stapling involves the use of modified amino acids that permit the creation of an all-hydrocarbon cross-link generated 


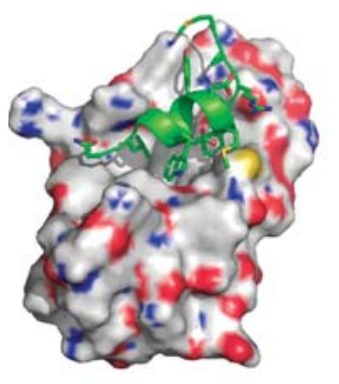

MPRFMDYWEGLN $(12-1)$
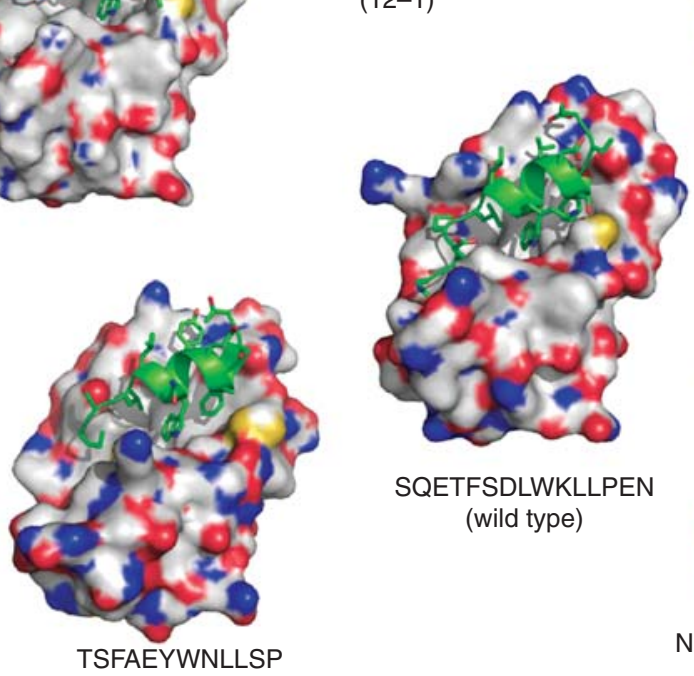

SQETFSDLWKLLPEN (wild type)

\section{(20)}


possible, using peptide aptamers, to show that simply blocking the p53 binding site on $\mathrm{Mdm} 2$ was sufficient to activate the p53 response and furthermore that this led to a great increase in $\mathrm{p} 53$ protein levels because $\mathrm{Mdm} 2$ was acting as an E3 ligase to degrade p53 in normal cells and tissues (Bottger et al. 1997). However the consequence of systemic p53 activation in an adult animal was still unclear and this of course lies at the heart of the issue of therapeutic index. Acute ablation of $\mathrm{Mdm} 2$ expression in adult tissues can lead to gross damage raising concerns that $\mathrm{Mdm} 2$ inhibitors might be excessively toxic (Ringshausen et al. 2006). However Mdm2 hypomorphic alleles in mice had shown that mild reductions in $\mathrm{Mdm} 2$ activity could be tolerated and indeed be tumor suppressive (Mendrysa et al. 2006). The first in vivo experiments with the Nutlins have been very encouraging because antitumor activity has been seen that is both p53 dependent and tumor selective (Vassilev et al. 2004). As this has also now been seen with the spiro-oxindoles as well, it is reasonable to conclude that p53 activation by these nongenotoxic compounds is well tolerated in normal tissues (Shangary et al. 2008). Conversely large surveys of p53 wildtype human leukemic cells have shown a consistent cytotoxic activity for nutlin that is encouraging clinical trials in this indication. In a recent very comprehensive study 100 primary human CLL cases were examined for their responses to Nutlin and M1 compounds (Saddler et al. 2008). All of the tumor cells that expressed wildtype p53 responded to both drugs whereas neither drug showed much inhibition of growth of p53 mutant human tumor cells in this series. The results of clinical trials with these agents are eagerly anticipated. Some concerns remain of course about Mdm2 as a target. First, will some unexpected on target toxicity be revealed by extended dosing schedules? Here it is promising to note that Nutlin induces a reversible cell cycle arrest in nontransformed human keratinocytes in culture (Cheok et al. 2010) and adult mice are resilient to several weeks of proliferation inhibition (Soucek et al. 2008). Second, how quickly will resistance arise? Studies using shRNA libraries have shown that, as expected,
Nutlin resistance can develop by inactivation of p53 but also surprisingly by loss of the DNA repair protein p53BP1 (Brummelkamp et al. 2006). We can anticipate that Mdm2 inhibitors will, like most targeted therapies, have to be used in judicious combinations.

\section{OTHER INHIBITORS OF Mdm2}

The Mdm2 protein is a complex and highly regulated molecule containing in addition to the amino-terminal p53 binding domain a zinc finger, a ring domain with E3 ligase activity for both ubiquitin and Nedd-8, and a central acidic domain (Toledo and Wahl 2007). Until recently Mdm2 had only be described in the vertebrates and was notably absent from the worm and fly genomes. Recently however it has been shown that like p53 $\mathrm{mdm} 2$ is present in very simple eukaryotes such as the placazoa (Lane et al. 2010). Although the amino-terminal domain dominates the interaction with $\mathrm{p} 53$, other sites of interaction with p53 have also been reported (Shimizu et al. 2002) and Mdm2 interacts with many other proteins including its other family member MdmX. This suggests that other sites on Mdm2 might also be targets for therapeutic intervention and indeed the tumor suppressor protein p19 Arf acts at least in part by binding to the acidic domain of Mdm2 and inhibiting its activity as a negative regulator of p53 (Midgley et al. 2000). There are strong suggestions that $\mathrm{Mdm} 2$ may also be involved in targeting proteins to the proteasome (Hjerpe et al.) and indeed the p53 activating compound JNJ-26854165 developed by Johnson and Johnson, and currently in clinical trial, seems to act at this level. It has also been possible to identify compounds that inhibit the E3 ligase activity of Mdm2 in biochemical screens but these molecules remain at an early stage of development.

\section{INHIBITORS OF MdmX}

In 1996, a second p53 binding protein that was related to Mdm2 in structure was discovered. $\mathrm{MdmX}(\mathrm{Mdm} 4)$ is not active as an E3 ligase but can form heteroligomers with Mdm2 and can act as a negative regulator of $\mathrm{p} 53$. The 
genetic knockout of $\mathrm{MdmX}$ is, like that of Mdm2, an embryonic lethal in the mouse that is rescued by simultaneous knockout of the p53 gene. So both $\mathrm{Mdm} 2$ and $\mathrm{MdmX}$ play nonredundant roles in the regulation of p53. The structural similarity between Mdm2 and MdmX extends to the amino-terminal p53 binding domain and many of the peptides described previously that bind $\mathrm{Mdm} 2$ also bind MdmX (Pazgier et al. 2009). Interestingly however detailed differences in the binding mode mean that the small molecule inhibitors such as Nutlin and MI-219 do not interact strongly with MdmX. Thus resistance to Nutlin can be conferred by overexpression of MdmX. This phenomenon is proving useful in asking how important $\mathrm{MdmX}$ versus $\mathrm{Mdm} 2$ is in inhibiting p53 function in particular human tumors. At least in the case of Retinoblastoma MdmX appears to be the dominate protein and MdmX gene amplification is common in this cancer. The search is thus on for both new small molecules that will inhibit the p53 MdmX interaction and also dual inhibitors that will block the binding sites of both Mdm2 and MdmX. Very recently the first MdmX inhibitors have been reported and though the data are quite preliminary they are also encouraging that like $\mathrm{Mdm} 2 \mathrm{MdmX}$ is a druggable target (Reed et al. 2010).

\section{SMALL MOLECULES ACTIVATING p53 VIA DIRECT INTERACTION WITH p53 ITSELF}

There are several reports of compounds that interact directly with p53 in vitro. Some of these have been tested in cells and there are various degrees of evidence suggesting that their effects occur through activation of $\mathrm{p} 53$. Three of these compounds (CP-31398, PRIMA-1, and PhiKan083) are thought to reactivate mutant p53 whereas RITA has been suggested to weaken the interaction of p53 with mdm 2 .

CP-31398 was selected from a biochemical screen for molecules promoting the stability of p53's DNA binding domain (DBD) using the wild-type-specific antibody PAb1620 (Foster et al. 1999; Mayer et al. 1999). CP-31398 can inhibit the growth of xenograft tumors in immunodeficient mice as well as the appearance of tumors in immunocompetent mice (Rao et al. 2008). CP-31398 also reduced UV-induced skin cancers (most of which are known to acquire p53 mutations) and this antitumor effect of CP-31398 did not occur in p53-null mice (El-Deiry 2007). In cell culture, CP-31398 inhibits growth of cells with mutant p53 and as well as with wild-type-p53 and there is evidence supporting that these effects could be explained through the stabilization of p53's structure by direct binding of the compound to p53 (Luu et al. 2002; Wang et al. 2003). In spite of these observations, it is not yet fully established how CP-31398 works in cells as it is possible that CP-31398 does not bind to p53 directly and may instead interact with DNA (Rippin et al. 2002).

PRIMA-1 was selected from the NCI Diversity Set of compounds for its ability to kill tumor cells that express mutant p53 more effectively than tumor cells that lack p53 (Bykov et al. 2002). Intravenous or intraperitoneal injection of PRIMA-1 suppresses the growth of human tumor xenografts derived from lung and breast carcinoma and osteosarcoma (Bykov et al. 2002) and inhibits chemically induced mammary carcinomas in rats (Benakanakere et al. 2009). Because of its positive effect on animal models and efficient killing of tumor cells in ex vivo experiments, PRIMA- ${ }^{\text {MET }}$ (or APR-246, a more efficient analog of PRIMA-1 [Bykov et al. 2005]) is being tested in a Phase I clinical trial. Elucidating the mechanism of action of this potential therapeutic is therefore becoming increasingly significant.

There is evidence that both PRIMA-1 and PRIMA-1 ${ }^{\text {MET }}$ induce the expression of mediators of p53-dependent apoptosis such as Puma, Noxa, and Bax in cells with mutant p53 (Shen et al. 2008; Wang et al. 2007). In addition, these compounds increase wild-type p53's as well as the p53R273H mutant's ability to cause cell death independently of their transcription factor function. This latter effect could be caused by an increased interaction of p53 with Bcl-2 family proteins in the cytoplasm (Chipuk et al. 2003). These and other results suggest that PRIMA-1 could reactivate mutant p53 or 
enhance a p53-like function (e.g., p73) in cells expressing mutant $\mathrm{p} 53$.

It has been recently observed that methylene quinuclidinone, a decomposition product of PRIMA-1 as well as PRIMA-1 ${ }^{\text {MET }}$, can alkylate cysteine residues in mutant p53 (Lambert et al. 2009). Interestingly, other suggested mutant p53 reactivating molecules, MIRA-1, STIMA-1, and CP-31398, could also have a potential to alkylate cysteines (Lambert et al. 2009). Supporting this notion, introducing purified full-length mutant p53 treated in vitro with PRIMA- $1^{\mathrm{MET}}$ induces apoptosis in tumor cells and this is associated with an increased expression of p53 apoptotic downstream targets (Lambert et al. 2009). Although this evidence supports that PRIMA-1/PRIMA- $1^{\text {MET }}$ decomposition products could also directly bind mutant p53 in cells, other mechanisms mediating p53-related effects need to be analyzed. In addition p53-independent effects of PRIMA-1 must be evaluated, because, at least in some circumstances, this compound does have effects in a p53-null background (Supiot et al. 2008).

PhiKan083 is a carbazol derivative that unlike the compounds described previously is designed to interact with a particular p53 mutant. The Y220C mutation creates a binding pocket in the core domain of $\mathrm{p} 53$ on the opposite face to the DBD (Joerger et al. 2006). The elucidation of this structure suggested that this mutation-induced crevice might constitute a potential target for compounds unique to tumor cells expressing the Y220C mutant of p53. In silico screening combined with rational drug design led to the identification of the small molecule PhiKan083 as a potential binder. Differential scanning calorimetry confirmed that binding of PhiKan083 raised the melting temperature of p53Y220C by $2^{\circ} \mathrm{C}$ and a high resolution X-ray structure of the p53-Y220CPhiKan083 complex showed the predicted binding site for PhiKan083 (Boeckler et al. 2008). Although the biological data on PhiKan083 is not available yet, it is the first example of mutant-specific reactivating molecule. The Y220C mutation is not a hot-spot mutation, but nevertheless it occurs at a similar frequency worldwide to tumors with the BCR-ABL translocation, which is one of the main targets of imatinib.

RITA was selected from the NCI diversity set of compounds for its ability to kill HCT116 colon cancer cells with wild-type p53 more efficiently than HCT116 cells null for p53. In addition, this compound was shown to inhibit tumor growth in vivo (Issaeva et al. 2004; Yang et al. 2009b) RITA is thought to bind to p53 directly and this is associated with an inhibition of the interaction between p53 and MDM2 (Issaeva et al. 2004). Unlike other activators of wild-type p53, RITA is an effective inducer of a p53 specific apoptotic response. One explanation for this observation is that the MDM2 released from $\mathrm{p} 53$ by RITA degrades $\mathrm{p} 21$ therefore weakening the cytostatic function of p53 (Enge et al. 2009). In addition, RITA can inhibit the expression of survival factors in a p53dependent manner. Whether binding to p53 is the only mechanism by which RITA increases p53 activity in cells is a matter of debate (Yang et al. 2009b). RITA is known to bind to multiple proteins (Rivera et al. 1999) and to activate the DNA damage response pathways (Nieves-Neira et al. 1999; Yang et al. 2009b). However, it is intriguing that the induction of markers of DNA damage (such as phosphorylation of CHK1 and histone H2AX) seems to occur only in cells harboring wild-type p53 (Yang et al. 2009a).

\section{SMALL MOLECULES ACTIVATING p53 BY INHIBITING CLASS III HISTONE DEACETYLASES}

Sirtuins or class III histone deacetylases (HDACs) are a group of NAD + dependent enzymes with protein deacetylase and/or ADP-ribosyl transferase activity. Mammals express seven sirtuin homologs (SirT1-7) with both or one of these enzymatic activities and diverse subcellular locations and substrates (Haigis and Guarente 2006; Michan and Sinclair 2007; van Leeuwen and Lain 2009). The role of sirtuins in cancer has recently stimulated interest as well as discussion. Sirtuins directly affect multiple substrates including tumor suppressors (e.g., p53 and $\mathrm{Rb}$ ), factors involved in cell migration (e.g., 
cortactin), and DNA repair proteins (e.g., Ku70 and NBS1). In addition, sirtuins, and in particular SirT1 ensures the silencing of genes that are aberrantly promoter hypermethylated in cancer (Pruitt et al. 2006).

SirT1 negatively regulates p53 (reviewed in van Leeuwen and Lain 2009), which together with its ability to promote cell migration (Zhang et al. 2008) suggests that inhibition of SirT1 could slow down tumor growth and spread. Also indicating a pro-oncogenic role for SirT1 and suggesting that some tumor types may be hypersensitive to sirtuin inhibition, the expression of SIRT1 is up-regulated in several types of cancer (Bradbury et al. 2005; Hida et al. 2007; Huffman et al. 2007; Stunkel et al. 2007). Aside from the expression levels of sirtuins, their degree of enzymatic activity with regards to $\mathrm{NAD}+$ availability in cancer cells or alterations in modulators of their function should also be considered. For example, DBC1 (deleted in breast cancer 1) has been shown to be an inhibitor of SirT1 activity (Zhao et al. 2008). On the other hand, reports derived from observations in SirT1 knockout mice demonstrate that sustained depletion of SirT1 gives rise to genomic instability. This unequivocally implies that SirT1 acts as a tumor suppressor (Firestein et al. 2008; Oberdoerffer et al. 2008; Wang et al. 2008b). Supporting such a role, and in contrast with the results mentioned previously, a decrease in SIRT1 expression has also been reported for a variety of tumors (Wang et al. 2008b). In gliomas and gastric carcinomas, the levels of SirT2, a sirtuin involved in tubulin deacetylation (North et al. 2003) and mitotic checkpoints (North and Verdin 2007) are also down-regulated (Hiratsuka et al. 2003).

The importance of p53's acetylation status at its carboxy-terminal lysines as well as at lysines 120 and 164 has been carefully evaluated (Tang et al. 2008). With regards to the role of sirtuins in the modulation of p53 there is evidence derived from genetic manipulation experiments in cultured cells supporting that SirT1 inhibition leads to the stabilization and activation of p53. SirT1 destabilizes p53 by catalyzing p53's deacetylation at lysine 382 (Langley et al. 2002; Luo et al. 2004; Vaziri et al. 2001), an event that may facilitate ubiquitination and proteasomal degradation of p53 as well as weaken p53's ability to bind DNA (Luo et al. 2004). Whether sirtuins affect the acetylation status of lysine residues other than 382 still needs to be established. Also supporting SirT1's negative effects on p53, cells derived from SirT1-deficient mice as well as cells treated with siRNAs against SirT1 show high levels of hyperacetylated p53 (Cheng et al. 2003; Ford et al. 2005), and a dominant-negative SirT1 mutant increases p53dependent transcriptional activity (Lain et al. 2008; Luo et al. 2001).

It is also interesting to note that SirT1 may not be the only sirtuin deacetylating p53: SirT7 a nucleolar sirtuin (Frye 2000) also interacts with p53 and deacetylates p53 in vitro. Accordingly, hyperacetylation of p53 has been observed in SirT7-deficient cells (Vakhrusheva et al. 2008). In addition there is some evidence indicating that SirT2 overexpression can lead to a decline in p53's transcription factor activity (Wang et al. 2008a). Altogether this information suggests that pharmacologic inhibition of sirtuins 1, 2, and/or 7 could give rise to an increase in $\mathrm{p} 53$ function.

A wide variety of unrelated sirtuin smallmolecule inhibitors have been discovered using biochemical sirtuin activity assays, yeast phenotypic screens, as well as phenotypic mammalian cell-based assays (reviewed in Lavu et al. 2008; Milne and Denu 2008). In many cases, these inhibitors are nonspecific for sirtuins, and in others their specificity has not yet been analyzed. Here we will describe sirtuin inhibitors that have been tested with regards to their effects on p53 in cells.

Sirtinol, the first small molecule sirtuin inhibitor identified, was initially described as being inactive on mammalian cells (Grozinger et al. 2001). Yet, in a later study, sirtinol-induced growth arrest and increased p53 levels were observed using concentrations above $50 \mu \mathrm{M}$ (Ota et al. 2007). Salermide, a sirtinol derivative, inhibits the protein deacetylase activities of purified SirT1 and SirT2 and causes apoptosis in cultured human cancer cell lines (Lara et al. 2008). The increased death rate was associated with the reactivation of proapoptotic 
genes epigenetically repressed by SirT1. Salermide did not significantly increase p53 levels in this study.

EX-527 is a potent SirT1 inhibitor in biochemical assays with IC50 values in the nanomolar range (Napper et al. 2005). However, this compound fails to increase p53 levels unless it is combined with a DNA-damaging agent (Solomon et al. 2006).

Splitomycin is another interesting sirtuin inhibitor(Bedalov et al. 2001) but of limited use because of its instability in cell culture conditions. In contrast, cambinol (Heltweg et al. 2006), a stable splitomycin-related compound that inhibits SirT1 and SirT2 deacetylase activities in vitro leads to increased levels of acetylated p53 and tubulin. It must be noted here that the effects on p53 can only be observed when cells are also incubated with etoposide. Cambinol is well tolerated as a single agent by epithelial cancer cells, whereas it is highly toxic to Burkitt lymphoma cells in a Bcl6 expression-dependent manner (Heltweg et al. 2006). Accordingly, cambinol decreases growth of xenograft tumors derived from a Bcl6-expressing Burkitt lymphoma cell line (Heltweg et al. 2006).

Suramin, which is used for the treatment of trypanosomiasis and onchocerciasis, is also a well-established sirtuin inhibitor (Schuetz et al. 2007). This compound increases p53 protein levels but fails to increase $\mathrm{p} 21^{\mathrm{CIP} 1 / \mathrm{WAF} 1}$ expression and does not activate the p53dependent G1 checkpoint (Howard et al. 1996).

Tenovins are clearly inducers of the p53 response as they were identified using a phenotypic screen based on the activation of p53's transcription factor function in cells (Lain et al. 2008). Tenovin-1 and its more watersoluble analog, tenovin-6, are active in mammalian cells in culture at low micromolar concentrations causing cell cycle arrest as well as apoptosis. Furthermore, tenovin-6 decreases tumor growth in vivo at $50 \mathrm{mg} / \mathrm{kg}$ as a single agent. Using a yeast genetic screen, biochemical assays, and target validation studies in mammalian cells, it was shown that tenovins are likely to act in cells through inhibition of the proteindeacetylating activities of SirT1 and SirT2 (Lain et al. 2008). Accordingly, the response to tenovin exposure in cells is accompanied by increases in the levels of both p53 and tubulin acetylation.

$3,2^{\prime}, 3^{\prime}, 4^{\prime}$-tetrahydroxychalcone is a polyphenol identified as an inhibitor of purified SirT1's ability to deacetylate recombinant p53 and a p53 derived peptide (Kahyo et al. 2008). In cells, this agent suppressed the cell growth, induced the hyperacetylation of endogenous p53 and increased endogenous $\mathrm{p} 21^{\mathrm{CIP} 1 / \mathrm{WAF} 1}$ expression.

As can be drawn from the results described previously, some sirtuin inhibitors can easily lead to the activation of p53 as single agents (e.g., sirtinol, suramin, tenovins, and $3,2^{\prime}, 3^{\prime}, 4^{\prime}$-tetrahydroxychalcone), whereas others (e.g., EX-527 and cambinol) need concomitant addition of DNA damaging agents such as etoposide to have an effect on p53. Lack of potency or stability of these compounds in cells could account for this, but this sort of analysis has not been performed. Among other explanations (van Leeuwen and Lain 2009), it could be argued that DNA damaging agents that, like etoposide, increase the p53 acetylation event could provide a better setting for detecting the effects of inhibiting deacetylation. This could suggest that sirtuin inhibitors that activate p53 as single agents may also be causing DNA damage. However, at least in the case of tenovins, there is no substantial increase in the appearance of standard markers for genotoxicity (Lain et al. 2008). On the other hand, suramin is known to also inhibit topoisomerase II (Bojanowski et al. 1992) an event that is likely to contribute to its ability to increase p53 levels.

From this information it can be drawn that pharmacologic inhibition of sirtuins, and in particular SirT1 and SirT2, can lead to tumorcell growth arrest and apoptosis as well as inhibition of tumor-cell spread. However, a careful assessment of the risk for genome instability arising from treatment with sirtuin inhibitors must be carried out before such compounds are taken to the clinic. Whether p53 status in tumors influences the efficiency of these compounds and the risk for genomic instability still needs to be evaluated further (Brooks and Gu 2009; van Leeuwen and Lain 2009). 


\section{SMALL MOLECULES ACTIVATING p53 BY INHIBITING NUCLEAR EXPORT}

Leptomycin B (LMB) (a Streptomyces sp. antibiotic) is a potent inhibitor of crm1, an exportin that mediates the transport from the nucleus to the cytoplasm of proteins containing HIV Rev type nuclear transport signals (NES) (reviewed in Lain et al. 1999) LMB is a Michael acceptor that covalently binds to a cysteine residue within the NES-recognizing sequence in crm1. Yeast strains expressing a crm1 mutant defective for interaction with LMB confer cells resistance to the compound. In addition, biotinylated LMB has been shown to pull-down crm1 from mammalian cell extracts. These experiments strongly support that LMB specifically targets crm 1 in cells.

Before its identification as an inhibitor of crm1 it was already known that LMB (elactocin, CI-940) and its derivatives (leptomycins A and kasuzamycins) efficiently kill tumor cells in culture at concentrations in the $0.2-2 \mathrm{nM}$ range (Roberts et al. 1986). LMB was also effective against pleiotropically resistant (to adriamycin, amsacrine, and mitroxantrone) P388 leukemia cells. In preclinical models, LMB administration showed a clear effect against P388 and L212 leukemias and against IP-implanted B16 melanoma, mammary adenocarcinoma 16/C and M5076 sarcoma. Later on, a phase-I trial was carried out (Newlands et al. 1996). No partial or complete responses were identified and dose-limiting toxicity (anorexia or malaise) was the same with all schedules tested. Additionally, there were serious difficulties in measuring the pharmacokinetic properties of LMB because of its fatty acid-like structure. After these results, further trials were not recommended.

Nevertheless, over the last years there has been a renewed interest in developing less toxic derivatives of this molecule (Koster et al. 2003; Mutka et al. 2009). Early in 2009 Kosan Biosciences reported a series of semisynthetic LMB derivatives with improved therapeutic windows (Mutka et al. 2009). As observed for LMB, exposure of cancer cells to these new compounds leads to nuclear export block and apoptosis. In contrast, and also in agreement with results obtained with LMB (Smart et al. 1999), these agents induce cell cycle arrest, but not apoptosis in normal lung fibroblasts. Most interestingly, these new nuclear export inhibitors (NEI) maintain the high potency of LMB, are up to 16-fold better tolerated than LMB in vivo, and show efficacy in mouse xenograft models. In light of these improvements, the high specificity of LMB for crm 1 as well as its enormous potency in cells, it is reasonable to include an update of the recent advances on the mechanisms by which treatment with this compound leads to p53 activation.

LMB activates p53-dependent transcription in cells even at subnanomolar concentrations (Lain et al. 1999; Menendez et al. 2003). This effect of LMB is likely to be at least in part caused by the stabilization of p53 from mdm2-mediated degradation. Accordingly, LMB increases p53 levels (Freedman and Levine 1998; Lain et al. 1999) and may protect it from mdm2mediated ubiquitination (Xirodimas et al. 2001). Additional work suggested that $\mathrm{mdm} 2$ as well as p53 have nuclear export signals that enable shuttling of these proteins out of the nucleus through crm1 (Roth 1999; Stommel et al. 1999; Zhang and Xiong 2001). However, it was not until 2007 when an interaction between p53 and crm1 was reported (Kanai et al. 2007). In this study, p53-crm1 complexes were detected by coimmunoprecipitation using purified proteins as well as extracts from cells expressing ectopic p53 and crm1. Interestingly, this interaction is inhibited by poly(ADPribosyl)ation of $\mathrm{p} 53$ by PARP-1. Because PARP-1 is activated in response to genotoxic stress, this work provides an elegant explanation for the accumulation of p53 in the nucleus on DNA damage. Shortly after, Cai and Liu (Cai and Liu 2008) presented evidence on the interaction between endogenous p53 and crm1 in cells by coimmunoprecipitation. In addition they reported that phosphorylation of p53 at Thr-55 induces this association as well as p53 nuclear export. Furthermore they observed that functional mdm2 promotes crm1-p53 complex formation in a Thr-55 phosphorylation-dependent way and requires an intact mdm2 RING finger domain. These results are 
in agreement with previous observations where accumulation of $\mathrm{p} 53$ in the nucleus by ubiquitin ligase deficient mutants of $\mathrm{mdm} 2$ was associated with inhibition of p53 nuclear export (Boyd et al. 2000; Geyer et al. 2000; Lohrum et al. 2001; Lu et al. 2000). Interestingly, Cai and Liu also correlated inhibition of Thr-55 phosphorylation by a dietary flavonoid, apigenin, with blocking of the crm1-p53 association.

All in all these studies tend to assume that $\mathrm{p} 53$ degradation occurs mainly in the cytoplasm. Howeer, there are other reports suggesting that p53 can also be degraded in the nuclear compartment (Joseph and Moll 2003; Joseph et al. 2003; Xirodimas et al. 2001). Despite extensive experimentation, the subcellular site(s) for p53 ubiquitination and degradation still remain unclear.

It is still possible that at least part of the effect of LMB on p53 may be indirect. Effects of LMB on mdm2's shuttling have not been reported, but it has been observed that LMB can interfere with complete degradation of human $\mathrm{mdm} 2$ leading to the appearance of a truncated form that could impair full length mdm2 activity (Menendez et al. 2003).

Interestingly, LMB's effect is not limited to cells where $\mathrm{p} 53$ degradation is mediated by $\mathrm{mdm} 2$. In cervical cancer cells carrying malignant strains of human papillomavirus (HPV), where p53's degradation is mainly caused by the viral oncogenic protein E6, p53's levels and transcriptional activity are also increased by LMB (Freedman and Levine 1998; Gray et al. 2007; Hietanen et al. 2000; Jolly et al. 2009; Koivusalo et al. 2006; Stewart et al. 2005). These observations may be of important therapeutic interest considering that, as recently reported (van der Watt et al. 2009), nucleocytoplasmic trafficking proteins $\mathrm{crm} 1$ and karyopherin beta1, are overexpressed in cervical cancer in comparison to normal tissue and are critical for cancer cell survival and proliferation. In this work the authors also provide evidence that down-regulation of crml with siRNA leads to increased levels of transcriptionally active p53.

The mechanism of action of LMB and its specificity would suggest that its ability to activate the p53 response does not involve direct
DNA damage. In fact, LMB does not induce substantial DNA damage in $\mathrm{HaCaT}$ cells even at micromolar concentrations, nor does it increase the level of phosphorylation of histone HA2X, a well-established marker of the DNA damage response (R. Berkson and S. Lain, unpublished). In agreement, Turner and coworkers (Turner et al. 2009) also detect little DNA damage in response to ratjadone $\mathrm{C}$, another $\mathrm{crm} 1$ inhibitor related to LMB. Nevertheless, inhibition of crm1 function may still have genotoxic effects. For example, crml inhibition is known to lead to accumulation of topoisomerase II $\alpha$ and increase DNA damage induced by topo II $\alpha$ inhibitors (Turner et al. 2009). Additionally, treatment with crm1 inhibitors may cause genomic instability because of the role of $\mathrm{crm} 1$ in centrosome duplication (Budhu and Wang 2005).

Whatever the exact mechanism(s) leading to the activation of the $\mathrm{p} 53$, our experience in screening more than 134,000 compounds for their ability to increase p53 transcription factor function in cells (Berkson et al. 2005; Lain et al. 2008; Staples et al. 2008) (Lee M. personal communication) leads us to conclude that LMB is, with Actinomycin D the most potent known activators of p53. Nonetheless, as described previously, possible genotoxicity of $\mathrm{crm} 1$ inhibitors should be taken into consideration for future clinical trials.

\section{SMALL MOLECULES ACTIVATING p53 BY TRANSCRIPTIONAL INHIBITION AND NUCLEOLAR DISRUPTION}

It has been realized since the pioneering work of Mike Kastan that DNA damage can activate the p53 response. Even very low levels of DNA damage are able to effectively turn on both p53 growth arrest and apoptotic responses. Because many chemotherapeutic drugs are DNA damaging agents this has lead to the broad assumption that their ability to induce p53 is because of their ability to damage DNA. This assumption is probably false and careful analysis using extended dose ranges is leading to the profound realization that many of these compounds have multiple modes of action. Of especial interest are a variety of clinical approved 
drugs or drugs in early clinical trial that, through different mechanisms cause an inhibition of transcription that result in nucleolar disruption. This nucleolar disruption is associated with defects in ribosome biogenesis that result in the release of free ribosomal proteins that can bind to $\mathrm{Mdm} 2$ and inhibit its function thus activating the p53 response (Zhang and Lu 2009). The induction of p53 dependant transcription is remarkably resilient to global transcriptional inhibition so that one is frequently faced with a situation in which general transcription is depressed but the p53 response is nevertheless leading to de novo transcription and translation of p53 target genes. This kind of response to stress shows strong parallels to the SOS response in prokaryotes and the heat shock response in eukaryotes. Compounds that activate p53 through this route include the CDK inhibitors such as Roscovitine (Dey et al. 2008; Lu et al. 2001), Flavopiridol (Demidenko and Blagosklonny 2004) and DRB, the inhibitors of Ribonucleotide production such as PALA (n-phosphonacetyl-L-aspartate) and pyrazofurin (Linke et al. 1996) and the RNA polymerase inhibitors such as Actinomycin D (Choong et al. 2009).

All of these compounds can act like Nutlin to produce a nongenotoxic reversible G1 arrest in normal cells, while inducing p53 dependant apoptosis in p53 wild-type tumor cells. Of course at higher doses they lose their p53 dependence and exert a more nonspecific toxic affect. Because DNA damage can also induce transcriptional inhibition the question arises as to whether DNA damage induces p53 solely through this route. This does not appear to be the case as the activation of p53 by double strand breaks is ATM dependant whereas its induction by actinomycin D for example is not. The key molecules responding to these different signals appear to be Mdm2 and MdmX and in very exciting recent data it is becoming possible to generate subtle mutations in Mdm2 and MdmX that confer selective loss of response of the p53 system to different agents. For example mutations in the Zinc finger region of Mdm2 block its binding to L5 and L11 and make cells nonresponsive to Actinomycin D at doses that stimulate a robust p53 response in normal cells (Lindstrom et al. 2007) whereas mutation in $\mathrm{MdmX}$ at amino acids that are required for phosphorylation induced binding to $14-3-3$ proteins produce mice that are resistant to ionizing radiation. Gene expression profiling studies have shown that low doses of Actinomycin D phenocopy the activity of Nutlin to a remarkable extent. This new data can both guide the clinical development of the new Mdm2 inhibitors but also suggest new applications doses and formulations for approved drugs (Choong et al. 2009).

\section{SMALL MOLECULES ACTIVATING p53 FAMILY MEMBERS IN A p53 MUTANT OR DEFICIENT BACKGROUND}

p53 family members are in many ways functionally similar to p53, but are rarely mutated in tumors. In particular, activation of the p53 homologue p73 can exert some of the transcription factor functions of p53. Hence, screening for small molecules that activate p73 is an interesting approach in the search for novel cancer therapeutics. Searching for small molecules that activate p73 but not p53 and only in a p53 deficient background offers an attractive opportunity to kill tumor cells selectively without causing damage to normal cells. With more than 2000 types of mutations described for p53, this approach enables one to target a much wider variety of tumors than strategies aimed at restoring the activity of a particular p53 mutant.

To date there are two reports on screens for small molecules that induce a p53-like transcription factor activity in p53 deficient cells.

In the first study (Wang et al. 2006), a bioluminescence cell-based screen was use to identify small molecules that activate $\mathrm{p} 53$-like responses and cell death in SW480 human colon adenocarcinoma cell line $(\mathrm{R} 273 \mathrm{H}, \mathrm{P} 309 \mathrm{~S}$ mutant p53) expressing a p53-responsive firefly luciferase reporter. Approximately 2000 chemical agents from the NCI Developmental Therapeutics Program's diversity set were subjected to this primary assay followed by a secondary screening procedure to select for small molecules that activate a p53-like transcriptional 
activity and also led to cell death at higher doses or at later time points. 33 compounds that fulfilled these properties were identified. Interestingly, five of these compounds were also identified in our pilot screen for inducers of p53 activity in a wild-type p53 cell context (Berkson et al. 2005) and include: NSC5159 (chartreusin, a clinically investigated topoisomerase I inhibitor); NSC123111 (a derivative of mitomycin $\mathrm{C}$ and clinically used DNA cross-linker); NSC146109 (2-(10-methyl-anthracen-9-ylmethyl)-isothiourea); NSC254681 (8acetyl-10-[ (3-amino-2,3,6-trideoxy-L-lyxohexopyranosyl)oxy]-7,9,10,12-tetrahydro-6,8,11trihydroxy-12-imino-1-methoxy-5(8H)-naphthacenone, a derivative of doxorubicin and clinically used DNA intercalator); and NSC639174 (9-glycineamido-20(S)-camptothecin hydrochloride, a derivative of camptothecin, clinically used topoisomerase I inhibitor). This confirms that certain DNA damaging agents can increase a p53-like activity in SW480 carrying (R273H, P309S) mutant p53.

Further analyses revealed that 13 of these 33 molecules increase expression of p 53 target genes such as $\mathrm{p}^{\mathrm{CIP} 1 / \mathrm{WAF} 1}$ and/or death receptor 5 (KILLER/DR5) in both p53 wild type and p53 knockout HCT116 cells. Two of these compounds (NSC143491 and NSC254681) increase p53 as well as p73 levels, whereas others (NSC5159 and NSC146109) do not induce significant p73 expression but induce a high p53-responsive transcriptional activity in the absence of p53. The remaining compounds, including NSC162908, which according to these authors has a remarkable ability to increase p21 and DR5 in HCT116 - / - cells, showed little effect on p53 and p73 levels in these assays. NSC5159, NSC143491, NSC162908, and NSC254681 caused apoptosis in HCT116p53+/+ as well as in HCT116p53 - / - cells. NSC143491 and NSC254681 but not NSC5159 and NSC162908 induced the appearance of markers for DNA damage, although as mentioned previously, NSC5159 is likely to function at least in part as a topoisomerase I inhibitor. Therefore, in conclusion, at least certain DNA damaging agents can induce a p53-like transcription function activity in the absence of p53 as well as in cells with mutant $\mathrm{p} 53$. The mechanism of action of NSC162908 remains highly intriguing and has been analyzed in another recent study (Hedstrom et al. 2009). In this work, NSC162908 is referred to as MITA and identified as an inducer of p53-dependent cell death that prevents the interaction of p53 with mdm2, thereby preventing p53's ubiquitination and degradation as well as increasing the levels of p53-downstream targets in the absence of the appearance of markers of DNA damage. According to the authors, this effect of MITA is restricted to tumor cells but does not occur in normal human fibroblasts.

In the paper by Wang and colleagues in vivo experiments were carried out to demonstrate potent antitumor effects of selected compounds NSC5159, NSC143491, NSC162908, and NSC254681, using either HCT116/p53(-/ - ) or DLD1 human colon tumor xenografts. All but compound NSC162908 (MITA) showed in vivo antitumor activity against xenograft tumors derived from these two p53 deficient cell lines. In view of the mechanistic results reported for MITA, it is possible that this compound may be more effective against tumors carrying wild-type p53.

In the second study, Kravchenko and colleagues (Kravchenko et al. 2008) set out to screen a 46,250 compound library (Chembridge DIVERSet) looking for molecules that increased $\beta$-galactosidase activity from a p53-dependent reporter construct in the A431 tumor cell line expressing the $\mathrm{R} 273 \mathrm{H}$ mutant of $\mathrm{p} 53$. A dosedependent induction of a p53-like activity in this reporter cell line was observed for 22 compounds in the collection. In a series of filtering assays it was shown that none of these $22 \mathrm{com}-$ pounds increased p53-like activity in a p53-null background and of these only 5 were unable to activate p53-like activity in a p53 wild-type background. One of these 5 compounds (\#5493343, 2-(4,5-dihydro-1,3-thiazol-2-ylthio)1-(3,4-dihydroxyphenyl)ethanone hydrobromide) showed activity at low micromolar concentrations and was named RETRA (reactivation of transcriptional reporter activity). In the A431 cells RETRA clearly increases p2 $1^{\mathrm{CIP} 1 / \mathrm{WAF} 1}$ and PUMA mRNA expression within $14 \mathrm{~h}$ of treatment, whereas expression 
from other p53-dependent genes such as hMDM2, GADD45, and IGFBP3 was not increased. Furthermore, RETRA could activate p53-like transcription in p53 null cells only after introducing mutant p53 in these cells. Conversely, partial inhibition of mutant p53 expression with shRNAs increased the activity of RETRA in the A431 cell line. Depletion of p63 in these cells had no effect but inhibition of p73 expression resulted in a significant loss of p53-like transcriptional activity induced by RETRA. In agreement with the selective effects of RETRA, transcriptionally active p73 (TAp73) protein levels were significantly increased in A431 cells but not in a cell line expressing wildtype p53 or in a p53-null cell line. In subsequent immunoprecipitation studies the authors show that one of the consequences of treatment of cells with RETRA is the release of p73 from inactive p53-p73 complexes. Mirroring the effects described previously, the growth inhibitory effect of RETRA was mild on a cell line expressing wild-type p53 as well as on two cell lines lacking p53. Furthermore, RETRA's antiproliferative and antiapoptotic effects on p53mutant cell lines were enhanced by the expression of shRNA to p53 and partially diminished by the expression of shRNA to p73. Finally, and suggesting a potential therapeutic use for this compound class, six daily i.p. injections with $0.4 \mathrm{mg}$ of RETRA delayed A431 xenograft tumor formation in athymic $n u / n u$ mice without significant levels of toxicity to the animals.

In summary, this work provides the first experimental evidence that in mutant p53-bearing cancer cells, loss of the p53 tumor-suppressor functions can be partially compensated for pharmacologically through activation of TAp73. Because this strategy may help developing therapeutics with minimal side effects and acting against a wide spectrum of cancer types it is important to elucidate RETRA's target(s) in cells acts as this may facilitate further structure activity relationship and optimization studies.

In another approach the activity of Nutlin has been examined in p53 null cells. Interestingly several groups have reported the activation of p53 responsive genes such as Puma and p21 and that Nutlin can act in effective synergy with chemotherapeutic drugs to induce apoptosis in p53 defective tumor cells. The effect seems to be linked to the activation of both E2F1 and p73 by nutlin treatment (Ambrosini et al. 2007; Kitagawa et al. 2008; Lau et al. 2008; Peirce and Findley 2009). This in turn is consistent with evidence that $\mathrm{Mdm} 2$ binds to both these proteins using the amino-terminal interaction domain that binds to p53 and is blocked by Nutlin.

\section{ACTIVATION OF p53 USING COMBINATIONS OF DRUGS}

Many current chemotherapeutics engage the DNA damage response pathways to induce a genotoxic response in cancer cells. However, these are met with increased collateral DNA damage and the possibility of secondary malignancies because of resistant tumor subclones. Therefore, finding ways to induce apoptosis without genotoxic burden on normal and tumor tissues is an attractive option. One attractive concept is the activation of p53 through targeting specific molecular pathways as described previously. The multiple pathways that can lead to p53 activation present an opportunity for simultaneously modifying these pathways using drug combinations. Indeed, drug combinations involving genotoxic agents (e.g., doxorubicin) have been explored and are found to be synergistic in inducing p53 accumulation and activation of apoptosis. A recent report (Cheok et al. 2007) on the combination of CDK inhibitors (Roscovitine and DRB) and nutlin-3 showed a clear synergism in the activation of p53 and apoptosis in p53 wild-type tumor cells. The combination retains the nongenotoxic nature characteristic of the individual compounds. More importantly, this provides proofof-concept that combinations of low doses of individual compounds that are not sufficiently dose potent on their own are effective in inducing the desired readouts. Therefore, combinations could be an effective method to increase therapeutic efficacy of p53 activating drugs while reducing the toxicities of the individual compounds. This approach is not without 
practical difficulties however as a fixed ratio of the compounds would have to be determined and formulated to work optimally together taking into account the variable $\mathrm{PK}$ and $\mathrm{PD}$ properties of the individual molecules.

\section{Cyclotherapy}

In the clinic, exploiting the differences between normal and tumor cells guided the key principles of chemotherapy. However, selective killing of tumor cells is difficult to achieve in reality because many chemotherapeutics target both dividing normal and tumor cells. Trying to find ways to increase the specificity or selectively of drugs for tumor cells are further impeded by the varied genetic background of different tumors. Furthermore, some mutations of p53 are correlated to increased drug resistance in tumor cells making it difficult to target p53 mutant cells. One potential way to increase drug selectivity is to identify druggable pathways with major roles in cell cycle arrest that are defective in p53 mutant cells. p53 is required for the G1-arrest and loss of $\mathrm{p} 53$ function abrogates the G1 checkpoint. Thus, activating the G1 checkpoint may protect normal tissues from toxicities of a subsequent chemotherapeutic targeted only at dividing cells. Proof-of-concept studies show that selective pharmacologic activation of the p53-dependent G1 arrest in normal cells but not p53 mutant cells protected p53 wild-type cells without compromising the sensitivity of p53 mutant cells to the effects of the second drug targeting the S-phase or mitosis (Carvajal et al. 2005) (Fig. 4). In particular, the reversibility of the temporary arrest on cells expressing wild-type p53 was shown by increased survival in colony counting assays only when cells were pretreated with nutlin-3 that specifically activated p53-dependent arrest (Cheok et al. 2010). The application of such a drug combination regimen in the clinic is optimistic with the recent demonstration that neutropenia (Sur et al. 2009), a major dose limiting toxicity of PLK inhibition, is reduced in mice pre-dosed with nutlin- 3 and that a temporary block of cell division in normal tissues is possible without much pathology. This combined with the finding described previously that some already approved drugs such as Actinomycin D (Choong et al. 2009) have doses at which they are extraordinarily specific at activating p53 reversibly and nongenotoxically is leading to the current development of clinical

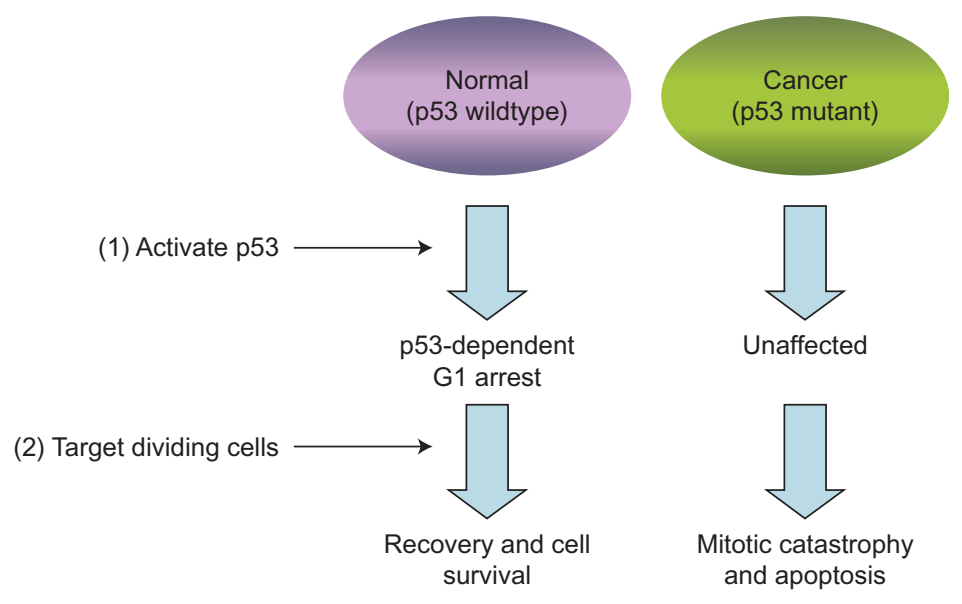

Figure 4. The principle of cyclcotherapy to exploit p53 mutation in tumor cells. Cyclotherapy can selectively kill p53 mutant tumor cells. Exposure to a nongenotoxic p53 activating coumpound induces a reversible cell cycle arrest in normal cells but not p53 mutant tumor cells which continue to divide in the presence of the drug. Subsequent treatment with an anti-S phase or antimitotic drug then kills the tumor cells but not the normal cells. Following drug removal; only the normal cells survive and can divide. 
protocols to test these ideas. Interestingly the major hurdle may be finding the "second" drug in the combination. This drug needs to be effective in killing p53 mutant cells but restrained in its use by toxicity to normal dividing tissue. An intense analysis of clinical data will be required to develop the optimal combination and schedule for these protocols.

\section{SUMMARY}

The rapid advances in understanding of the p53 pathway have led to many different approaches to p53 based cancer therapy and the field has excited great interest both academically and commercially. In many areas the p53 system has become the vanguard for new approaches such as the development of small molecule protein-protein interactions inhibitors, the identification of new targets by chemical biology screens and the use of gene therapy and drug combinations. Many questions remain to be answered however and some are proving elusive. A key area where increased understanding is vitally needed is how a cell in which p53 is activated selects its response between reversible growth arrest apoptosis or senescence. How are these responses different between normal tissues and cancer cells and what can be done to enhance these differences?

\section{REFERENCES}

Ambrosini G, Sambol EB, Carvajal D, Vassilev LT, Singer S, Schwartz GK. 2007. Mouse double minute antagonist Nutlin-3a enhances chemotherapy-induced apoptosis in cancer cells with mutant p53 by activating E2F1. Oncogene 26: 3473-3481.

Barak Y, Juven T, Haffner R, Oren M. 1993. mdm2 expression is induced by wild type p53 activity. $E M B O J \mathbf{1 2}$ : 461-468.

Bazan-Peregrino M, Carlisle RC, Hernandez-Alcoceba R, Iggo R, Homicsko K, Fisher KD, Hallden G, Mautner V, Shen Y, Seymour LW. 2008. Comparison of molecular strategies for breast cancer virotherapy using oncolytic adenovirus. Hum Gene Ther 19: 873-886.

Bedalov A, Gatbonton T, Irvine WP, Gottschling DE, Simon JA. 2001. Identification of a small molecule inhibitor of Sir2p. Proc Natl Acad Sci 98: 15113-15118.

Benakanakere I, Besch-Williford C, Ellersieck MR, Hyder SM. 2009. Regression of progestin-accelerated 7,12dimethylbenz[a]anthracene-induced mammary tumors in Sprague-Dawley rats by p53 reactivation and induction of massive apoptosis: A pilot study. Endocr Relat Cancer 16: $85-98$.

Berkson RG, Hollick JJ, Westwood NJ, Woods JA, Lane DP, Lain S. 2005. Pilot screening programme for small molecule activators of p53. Int J Cancer 115: 701-710.

Bernal F, Tyler AF, Korsmeyer SJ, Walensky LD, Verdine GL. 2007. Reactivation of the p53 tumor suppressor pathway by a stapled p53 peptide. JAm Chem Soc 129: 2456-2457.

Bischoff JR, Kirn DH, Williams A, Heise C, Horn S, Muna M, Ng L, Nye JA, Sampson-Johannes A, Fattaey A, et al. 1996. An adenovirus mutant that replicates selectively in p53-deficient human tumor cells. Science 274: 373-376.

Boeckler FM, Joerger AC, Jaggi G, Rutherford TJ, Veprintsev DB, Fersht AR. 2008. Targeted rescue of a destabilized mutant of p53 by an in silico screened drug. Proc Natl Acad Sci 105: 10360-10365.

Bojanowski K, Lelievre S, Markovits J, Couprie J, Jacquemin-Sablon A, Larsen AK. 1992. Suramin is an inhibitor of DNA topoisomerase II in vitro and in Chinese hamster fibrosarcoma cells. Proc Natl Acad Sci 89: 3025-3029.

Bottger A, Bottger V, Sparks A, Liu WL, Howard SF, Lane DP. 1997. Design of a synthetic Mdm2-binding mini protein that activates the p53 response in vivo. Curr Biol 7: 860-869.

Bottger V, Bottger A, Howard SF, Picksley SM, Chene P, Garcia-Echeverria C, Hochkeppel HK, Lane DP. 1996. Identification of novel mdm2 binding peptides by phage display. Oncogene 13: 2141-2147.

Boyd SD, Tsai KY, Jacks T. 2000. An intact HDM2 RING-finger domain is required for nuclear exclusion of p53. Nat Cell Biol 2: 563-568.

Bradbury CA, Khanim FL, Hayden R, Bunce CM, White DA, Drayson MT, Craddock C, Turner BM. 2005. Histone deacetylases in acute myeloid leukaemia show a distinctive pattern of expression that changes selectively in response to deacetylase inhibitors. Leukemia 19: 1751-1759.

Brooks CL, Gu W. 2009. How does SIRT1 affect metabolism, senescence and cancer? Nat Rev Cancer 9: 123-128.

Brummelkamp TR, Fabius AW, Mullenders J, Madiredjo M, Velds A, Kerkhoven RM, Bernards R, Beijersbergen RL. 2006. An shRNA barcode screen provides insight into cancer cell vulnerability to MDM2 inhibitors. Nat Chem Biol 2: 202-206.

Budhu AS, Wang XW. 2005. Loading and unloading: Orchestrating centrosome duplication and spindle assembly by Ran/Crm1. Cell Cycle 4: 1510-1514.

Bykov VJ, Issaeva N, Shilov A, Hultcrantz M, Pugacheva E, Chumakov P, Bergman J, Wiman KG, Selivanova G. 2002. Restoration of the tumor suppressor function to mutant p53 by a low-molecular-weight compound. Nat Med 8: 282-288.

Bykov VJ, Zache N, Stridh H, Westman J, Bergman J, Selivanova G, Wiman KG. 2005. PRIMA-1(MET) synergizes with cisplatin to induce tumor cell apoptosis. Oncogene 24: 3484-3491.

Cahilly-Snyder L, Yang-Feng T, Francke U, George DL. 1987. Molecular analysis and chromosomal mapping of amplified genes isolated from a transformed mouse $3 \mathrm{~T} 3$ cell line. Somat Cell Mol Genet 13: 235-244. 
Cai X, Liu X. 2008. Inhibition of Thr-55 phosphorylation restores p53 nuclear localization and sensitizes cancer cells to DNA damage. Proc Natl Acad Sci 105: 1695816963.

Carvajal D, Tovar C, Yang H, Vu BT, Heimbrook DC, Vassilev LT. 2005. Activation of $\mathrm{p} 53$ by MDM2 antagonists can protect proliferating cells from mitotic inhibitors. Cancer Res 65: 1918-1924.

Chen J, Marechal V, Levine AJ. 1993. Mapping of the p53 and $\mathrm{mdm}-2$ interaction domains. Mol Cell Biol 13: 4107-4114.

Cheng HL, Mostoslavsky R, Saito S, Manis JP, Gu Y, Patel P, Bronson R, Appella E, Alt FW, Chua KF. 2003. Developmental defects and p53 hyperacetylation in Sir2 homolog (SIRT1)-deficient mice. Proc Natl Acad Sci 100: 10794-10799.

Cheok CF, Dey A, Lane DP. 2007. Cyclin-dependent kinase inhibitors sensitize tumor cells to nutlin-induced apoptosis: A potent drug combination. Mol Cancer Res 5: $1133-1145$.

Cheok CF, Kua N, Kaldis P, Lane D. 2010. Combination of Nutlin-3 and VX-680 selectively targets p53 mutant cells with reversible effects on cells expressing wildtype p53. Cell Death Differ (in press).

Chipuk JE, Maurer U, Green DR, Schuler M. 2003. Pharmacologic activation of p53 elicits Bax-dependent apoptosis in the absence of transcription. Cancer Cell 4: 371-381.

Choong ML, Yang H, Lee MA, Lane DP. 2009. Specific activation of the p53 pathway by low dose actinomycin $\mathrm{D}$ : A new route to p53 based cyclotherapy. Cell Cycle 8: 2810-2818.

DeLeo AB. 1998. p53-based immunotherapy of cancer. Crit Rev Immunol 18: 29-35.

Demidenko ZN, Blagosklonny MV. 2004. Flavopiridol induces $\mathrm{p} 53$ via initial inhibition of $\mathrm{Mdm} 2$ and $\mathrm{p} 21$ and, independently of $\mathrm{p} 53$, sensitizes apoptosis-reluctant cells to tumor necrosis factor. Cancer Res 64: 3653-3660.

Dey A, Wong ET, Cheok CF, Tergaonkar V, Lane DP. 2008. R-Roscovitine simultaneously targets both the p53 and NF-kappaB pathways and causes potentiation of apoptosis: Implications in cancer therapy. Cell Death Differ 15: 263-273.

Ding K, Lu Y, Nikolovska-Coleska Z, Wang G, Qiu S, Shangary S, Gao W, Qin D, Stuckey J, Krajewski K, et al. 2006. Structure-based design of spiro-oxindoles as potent, specific small-molecule inhibitors of the MDM2-p53 interaction. J Med Chem 49: 3432-3435.

El-Deiry WS. 2007. Targeting mutant p53 shows promise for sunscreens and skin cancer. J Clin Invest 117: 3658-3660.

Enge M, Bao W, Hedstrom E, Jackson SP, Moumen A, Selivanova G. 2009. MDM2-dependent downregulation of p21 and hnRNP K provides a switch between apoptosis and growth arrest induced by pharmacologically activated p53. Cancer Cell 15: 171-183.

Farmer H, McCabe N, Lord CJ, Tutt AN, Johnson DA, Richardson TB, Santarosa M, Dillon KJ, Hickson I, Knights C, et al. 2005. Targeting the DNA repair defect in BRCA mutant cells as a therapeutic strategy. Nature 434: 917-921.

Firestein R, Blander G, Michan S, Oberdoerffer P, Ogino S, Campbell J, Bhimavarapu A, Luikenhuis S, de Cabo R,
Fuchs C, et al. 2008. The SIRT1 deacetylase suppresses intestinal tumorigenesis and colon cancer growth. PLoS ONE 3: e2020.

Ford J, Jiang M, Milner J. 2005. Cancer-specific functions of SIRT1 enable human epithelial cancer cell growth and survival. Cancer Res 65: 10457-10463.

Foster BA, Coffey HA, Morin MJ, Rastinejad F. 1999. Pharmacological rescue of mutant p53 conformation and function. Science 286: 2507-2510.

Freedman DA, Levine AJ. 1998. Nuclear export is required for degradation of endogenous p53 by MDM2 and human papillomavirus E6. Mol Cell Biol 18: 7288-7293.

Frye RA. 2000. Phylogenetic classification of prokaryotic and eukaryotic Sir2-like proteins. Biochem Biophys Res Commun 273: 793-798.

Geyer RK, Yu ZK, Maki CG. 2000. The MDM2 RING-finger domain is required to promote p53 nuclear export. Nat Cell Biol 2: 569-573.

Grasberger BL, Lu T, Schubert C, Parks DJ, Carver TE, Koblish HK, Cummings MD, LaFrance LV, Milkiewicz KL, Calvo RR, et al. 2005. Discovery and cocrystal structure of benzodiazepinedione HDM2 antagonists that activate p53 in cells. J Med Chem 48: 909-912.

Gray LJ, Bjelogrlic P, Appleyard VC, Thompson AM, Jolly CE, Lain S, Herrington CS. 2007. Selective induction of apoptosis by leptomycin B in keratinocytes expressing HPV oncogenes. Int J Cancer 120: 2317-2324.

Grozinger CM, Chao ED, Blackwell HE, Moazed D, Schreiber SL. 2001. Identification of a class of small molecule inhibitors of the sirtuin family of NAD-dependent deacetylases by phenotypic screening. J Biol Chem 276: 38837-38843.

Haigis MC, Guarente LP. 2006. Mammalian sirtuinsemerging roles in physiology, aging, and calorie restriction. Genes Dev 20: 2913-2921.

Hedstrom E, Issaeva N, Enge M, Selivanova G. 2009. Tumorspecific induction of apoptosis by a p53-reactivating compound. Exp Cell Res 315: 451-461.

Heltweg B, Gatbonton T, Schuler AD, Posakony J, Li H, Goehle S, Kollipara R, Depinho RA, Gu Y, Simon JA, et al. 2006. Antitumor activity of a small-molecule inhibitor of human silent information regulator 2 enzymes. Cancer Res 66: 4368-4377.

Hida Y, Kubo Y, Murao K, Arase S. 2007. Strong expression of a longevity-related protein, SIRT1, in Bowen's disease. Arch Dermatol Res 299: 103-106.

Hietanen S, Lain S, Krausz E, Blattner C, Lane DP. 2000. Activation of p53 in cervical carcinoma cells by small molecules. Proc Natl Acad Sci 97: 8501-8506.

Hiratsuka M, Inoue T, Toda T, Kimura N, Shirayoshi $\mathrm{Y}$, Kamitani H, Watanabe T, Ohama E, Tahimic CG, Kurimasa A, et al. 2003. Proteomics-based identification of differentially expressed genes in human gliomas: Down-regulation of SIRT2 gene. Biochem Biophys Res Commun 309: 558-566.

Hjerpe R, Aillet F, Lopitz-Otsoa F, Lang V, Torres-Ramos M, Farras R, Hay RT, Rodriguez MS. 2010. Oligomerization conditions Mdm2-mediated efficient p53 polyubiquitylation but not its proteasomal degradation. Int J Biochem Cell Biol doi: 10.1016/jbiocel.2010.012010. 
Hoffmann TK, Donnenberg AD, Finkelstein SD, Donnenberg VS, Friebe-Hoffmann U, Myers EN, Appella E, DeLeo AB, Whiteside TL. 2002. Frequencies of tetramer+ $T$ cells specific for the wild-type sequence p53(264-272) peptide in the circulation of patients with head and neck cancer. Cancer Res 62: 3521-3529.

Howard SP, Park SJ, Hughes-Davies L, Coleman CN, Price BD. 1996. Suramin increases p53 protein levels but does not activate the p53-dependent G1 checkpoint. Clin Cancer Res 2: 269-276.

Huffman DM, Grizzle WE, Bamman MM, Kim JS, Eltoum IA, Elgavish A, Nagy TR. 2007. SIRT1 is significantly elevated in mouse and human prostate cancer. Cancer Res 67: 6612-6618.

Issaeva N, Bozko P, Enge M, Protopopova M, Verhoef LG, Masucci M, Pramanik A, Selivanova G. 2004. Small molecule RITA binds to p53, blocks p53-HDM-2 interaction and activates p53 function in tumors. Nat Med 10: $1321-1328$.

Jiang M, Milner J. 2002. Selective silencing of viral gene expression in HPV-positive human cervical carcinoma cells treated with siRNA, a primer of RNA interference. Oncogene 21: 6041-6048.

Joerger AC, Ang HC, Fersht AR. 2006. Structural basis for understanding oncogenic p53 mutations and designing rescue drugs. Proc Natl Acad Sci 103: 15056-15061.

Jolly CE, Gray LJ, Parish JL, Lain S, Herrington CS. 2009. Leptomycin B induces apoptosis in cells containing the whole HPV 16 genome. Int J Oncol 35: 649-656.

Joseph TW, Moll UM. 2003. Analysis of nuclear and cytoplasmic degradation of p53 in cells after stress. Methods Mol Biol 234: 211-217.

Joseph TW, Zaika A, Moll UM. 2003. Nuclear and cytoplasmic degradation of endogenous p53 and HDM2 occurs during down-regulation of the $\mathrm{p} 53$ response after multiple types of DNA damage. FASEB J 17: 1622-1630.

Kahyo T, Ichikawa S, Hatanaka T, Yamada MK, Setou M. 2008. A novel chalcone polyphenol inhibits the deacetylase activity of SIRT1 and cell growth in HEK293T cells. J Pharmacol Sci 108: 364-371.

Kanai M, Hanashiro K, Kim SH, Hanai S, Boulares AH, Miwa M, Fukasawa K. 2007. Inhibition of Crm1-p53 interaction and nuclear export of $\mathrm{p} 53$ by poly(ADP-ribosyl)ation. Nat Cell Biol 9: 1175-1183.

Kitagawa M, Aonuma M, Lee SH, Fukutake S, McCormick F. 2008. E2F-1 transcriptional activity is a critical determinant of Mdm2 antagonist-induced apoptosis in human tumor cell lines. Oncogene 27: 5303-5314.

Koivusalo R, Mialon A, Pitkanen H, Westermarck J, Hietanen S. 2006. Activation of p53 in cervical cancer cells by human papillomavirus E6 RNA interference is transient, but can be sustained by inhibiting endogenous nuclear export-dependent p53 antagonists. Cancer Res 66: $11817-11824$.

Koster M, Lykke-Andersen S, Elnakady YA, Gerth K, Washausen P, Hofle G, Sasse F, Kjems J, Hauser H. 2003. Ratjadones inhibit nuclear export by blocking CRM1/ exportin 1. Exp Cell Res 286: 321-331.

Kranz D, Dobbelstein M. 2006. Nongenotoxic p53 activation protects cells against $\mathrm{S}$-phase-specific chemotherapy. Cancer Res 66: 10274-10280.
Kravchenko JE, Ilyinskaya GV, Komarov PG, Agapova LS, Kochetkov DV, Strom E, Frolova EI, Kovriga I, Gudkov AV, Feinstein E, et al. 2008. Small-molecule RETRA suppresses mutant p53-bearing cancer cells through a p73-dependent salvage pathway. Proc Natl Acad Sci 105: 6302-6307.

Kussie PH, Gorina S, Marechal V, Elenbaas B, Moreau J, Levine AJ, Pavletich NP. 1996. Structure of the MDM2 oncoprotein bound to the p53 tumor suppressor transactivation domain. Science 274: 948-953.

Lain S, Hollick JJ, Campbell J, Staples OD, Higgins M, Aoubala M, McCarthy A, Appleyard V, Murray KE, Baker L, et al. 2008. Discovery, in vivo activity, and mechanism of action of a small-molecule p53 activator. Cancer Cell 13: $454-463$.

Lain S, Midgley C, Sparks A, Lane EB, Lane DP. 1999. An inhibitor of nuclear export activates the p53 response and induces the localization of HDM2 and p53 to U1A-positive nuclear bodies associated with the PODs. Exp Cell Res 248: 457-472.

Lambert JM, Gorzov P, Veprintsev DB, Soderqvist M, Segerback D, Bergman J, Fersht AR, Hainaut P, Wiman KG, Bykov VJ. 2009. PRIMA-1 reactivates mutant p53 by covalent binding to the core domain. Cancer Cell 15: 376-388.

Lane DP, Cheok CF, Brown C, Madhumalar A, Ghadessy FJ, Verma C. 2010. Mdm2 and p53 are highly conserved from placozoans to man. Cell Cycle 9: 540-547.

Langley E, Pearson M, Faretta M, Bauer UM, Frye RA, Minucci S, Pelicci PG, Kouzarides T. 2002. Human SIR2 deacetylates p53 and antagonizes PML/p53induced cellular senescence. Embo J 21: 2383-2396.

Lara E, Mai A, Calvanese V, Altucci L, Lopez-Nieva P, Martinez-Chantar ML, Varela-Rey M, Rotili D, Nebbioso A, Ropero S, et al. 2008. Salermide, a Sirtuin inhibitor with a strong cancer-specific proapoptotic effect. Oncogene 28: 781-791.

Lau LM, Nugent JK, Zhao X, Irwin MS. 2008. HDM2 antagonist Nutlin-3 disrupts p73-HDM2 binding and enhances p73 function. Oncogene 27: 997-1003.

Lauwen MM, Zwaveling S, de Quartel L, Ferreira Mota SC, Grashorn JA, Melief CJ, van der Burg SH, Offringa R. 2008. Self-tolerance does not restrict the CD4+ T-helper response against the p53 tumor antigen. Cancer Res 68: 893-900.

Lavu S, Boss O, Elliott PJ, Lambert PD. 2008. Sirtuins-novel therapeutic targets to treat age-associated diseases. Nat Rev Drug Discov 7: 841-853.

Lindstrom MS, Jin A, Deisenroth C, White Wolf G, Zhang Y. 2007. Cancer-associated mutations in the MDM2 zinc finger domain disrupt ribosomal protein interaction and attenuate MDM2-induced p53 degradation. Mol Cell Biol 27: 1056-1068.

Linke SP, Clarkin KC, Di Leonardo A, Tsou A, Wahl GM. 1996. A reversible, p53-dependent G0/G1 cell cycle arrest induced by ribonucleotide depletion in the absence of detectable DNA damage. Genes Develop 10: 934-947.

Lohrum MA, Woods DB, Ludwig RL, Balint E, Vousden KH. 2001. C-terminal ubiquitination of p53 contributes to nuclear export. Mol Cell Biol 21: 8521-8532. 
Lu W, Chen L, Peng Y, Chen J. 2001. Activation of p53 by roscovitine-mediated suppression of MDM2 expression. Oncogene 20: 3206-3216.

Lu W, Pochampally R, Chen L, Traidej M, Wang Y, Chen J. 2000. Nuclear exclusion of p53 in a subset of tumors requires MDM2 function. Oncogene 19: 232-240.

Luo J, Li M, Tang Y, Laszkowska M, Roeder RG, Gu W. 2004. Acetylation of p53 augments its site-specific DNA binding both in vitro and in vivo. Proc Natl Acad Sci 101: 2259-2264.

Luo J, Nikolaev AY, Imai S, Chen D, Su F, Shiloh A, Guarente L, Gu W. 2001. Negative control of p53 by Sir2alpha promotes cell survival under stress. Cell 107: 137-148.

Luu Y, Bush J, Cheung KJ Jr, Li G. 2002. The p53 stabilizing compound CP-31398 induces apoptosis by activating the intrinsic Bax/mitochondrial/caspase-9 pathway. Exp Cell Res 276: 214-222.

Martins CP, Brown-Swigart L, Evan GI. 2006. Modeling the therapeutic efficacy of p53 restoration in tumors. Cell 127: 1323-1334.

Mayer TU, Kapoor TM, Haggarty SJ, King RW, Schreiber SL, Mitchison TJ. 1999. Small molecule inhibitor of mitotic spindle bipolarity identified in a phenotype-based screen. Science 286: 971-974.

Mendrysa SM, O'Leary KA, McElwee MK, Michalowski J, Eisenman RN, Powell DA, Perry ME. 2006. Tumor suppression and normal aging in mice with constitutively high p53 activity. Genes Develop 20: 16-21.

Menendez S, Higgins M, Berkson RG, Edling C, Lane DP, Lain S. 2003. Nuclear export inhibitor leptomycin B induces the appearance of novel forms of human Mdm2 protein. Br J Cancer 88: 636-643.

Michan S, Sinclair D. 2007. Sirtuins in mammals: Insights into their biological function. Biochem J 404: 1-13.

Midgley CA, Desterro JM, Saville MK, Howard S, Sparks A, Hay RT, Lane DP. 2000. An N-terminal p14ARF peptide blocks Mdm2-dependent ubiquitination in vitro and can activate p53 in vivo. Oncogene 19: 2312-2323.

Milne JC, Denu JM. 2008. The Sirtuin family: Therapeutic targets to treat diseases of aging. Curr Opin Chem Biol 12: $11-17$

Moellering RE, Cornejo M, Davis TN, Del Bianco C, Aster JC, Blacklow SC, Kung AL, Gilliland DG, Verdine GL, Bradner JE. 2009. Direct inhibition of the NOTCH transcription factor complex. Nature 462: 182-188.

Momand J, Zambetti GP, Olson DC, George D, Levine AJ. 1992. The mdm-2 oncogene product forms a complex with the p53 protein and inhibits p53-mediated transactivation. Cell 69: 1237-1245.

Montes de Oca Luna R, Wagner DS, Lozano G. 1995. Rescue of early embryonic lethality in mdm2-deficient mice by deletion of p53. Nature 378: 203-206.

Muller P, Hrstka R, Coomber D, Lane DP, Vojtesek B. 2008 Chaperone-dependent stabilization and degradation of p53 mutants. Oncogene 27: 3371-3383.

Mutka SC, Yang WQ, Dong SD, Ward SL, Craig DA, Timmermans PB, Murli S. 2009. Identification of nuclear export inhibitors with potent anticancer activity in vivo. Cancer Res 69: 510-517.

Napper AD, Hixon J, McDonagh T, Keavey K, Pons JF, Barker J, Yau WT, Amouzegh P, Flegg A, Hamelin E, et al. 2005.
Discovery of indoles as potent and selective inhibitors of the deacetylase SIRT1. J Med Chem 48: 8045-8054.

Newlands ES, Rustin GJ, Brampton MH. 1996. Phase I trial of elactocin. Br J Cancer 74: 648-649.

Nieves-Neira W, Rivera MI, Kohlhagen G, Hursey ML, Pourquier P, Sausville EA, Pommier Y. 1999. DNA protein cross-links produced by NSC 652287, a novel thiophene derivative active against human renal cancer cells. $\mathrm{Mol}$ Pharmacol 56: 478-484.

North BJ, Verdin E. 2007. Mitotic regulation of SIRT2 by cyclin-dependent kinase 1-dependent phosphorylation. J Biol Chem 282: 19546-19555.

North BJ, Marshall BL, Borra MT, Denu JM, Verdin E. 2003. The human Sir2 ortholog, SIRT2, is an NAD+-dependent tubulin deacetylase. Mol Cell 11: 437-444.

O'Shea CC, Johnson L, Bagus B, Choi S, Nicholas C, Shen A, Boyle L, Pandey K, Soria C, Kunich J, et al. 2004. Late viral RNA export, rather than p53 inactivation, determines ONYX-015 tumor selectivity. Cancer Cell 6: 611-623.

O'Shea CC, Soria C, Bagus B, McCormick F. 2005. Heat shock phenocopies E1B-55K late functions and selectively sensitizes refractory tumor cells to ONYX-015 oncolytic viral therapy. Cancer Cell 8: 61-74.

Oberdoerffer P, Michan S, McVay M, Mostoslavsky R, Vann J, Park SK, Hartlerode A, Stegmuller J, Hafner A, Loerch P, et al. 2008. SIRT1 redistribution on chromatin promotes genomic stability but alters gene expression during aging. Cell 135: 907-918.

Ota H, Akishita M, Eto M, Iijima K, Kaneki M, Ouchi Y. 2007. Sirt1 modulates premature senescence-like phenotype in human endothelial cells. J Mol Cell Cardiol 43: 571-579.

Pazgier M, Liu M, Zou G, Yuan W, Li C, Li J, Monbo J, Zella D, Tarasov SG, Lu W. 2009. Structural basis for highaffinity peptide inhibition of p53 interactions with MDM2 and MDMX. Proc Natl Acad Sci 106: 4665-4670.

Peirce SK, Findley HW. 2009. The MDM2 antagonist nutlin3 sensitizes p53-null neuroblastoma cells to doxorubicin via E2F1 and TAp73. Int J Oncol 34: 1395-1402.

Phelan A, Elliott G, O'Hare P. 1998. Intercellular delivery of functional p53 by the herpesvirus protein VP22. Nat Biotechnol 16: 440-443.

Picksley SM, Vojtesek B, Sparks A, Lane DP. 1994. Immunochemical analysis of the interaction of $\mathrm{p} 53$ with MDM2;fine mapping of the MDM2 binding site on p53 using synthetic peptides. Oncogene 9: 2523-2529.

Pruitt K, Zinn RL, Ohm JE, McGarvey KM, Kang SH, Watkins DN, Herman JG, Baylin SB. 2006. Inhibition of SIRT1 reactivates silenced cancer genes without loss of promoter DNA hypermethylation. PLoS Genet 2: e40.

Rao CV, Swamy MV, Patlolla JM, Kopelovich L. 2008. Suppression of familial adenomatous polyposis by CP31398, a TP53 modulator, in APCmin/+ mice. Cancer Res 68: 7670-7675.

Reed D, Shen Y, Shelat A, Arnold A, Ferreira A, Zhu F, Mills N, Smithson D, Regni C, Bashford D, et al. 2010. Identification and characterization of the first small-molecule inhibitor of MDMX. J Biol Chem M109.056747.

Renzing J, Lane DP. 1995. p53-dependent growth arrest following calcium phosphate-mediated transfection of murine fibroblasts. Oncogene 10: 1865-1868. 
Ringshausen I, O'Shea CC, Finch AJ, Swigart LB, Evan GI. 2006. Mdm2 is critically and continuously required to suppress lethal p53 activity in vivo. Cancer Cell 10: 501-514.

Rippin TM, Bykov VJ, Freund SM, Selivanova G, Wiman KG, Fersht AR. 2002. Characterization of the p53-rescue drug CP-31398 in vitro and in living cells. Oncogene 21: 2119-2129.

Rivera MI, Stinson SF, Vistica DT, Jorden JL, Kenney S, Sausville EA. 1999. Selective toxicity of the tricyclic thiophene NSC 652287 in renal carcinoma cell lines: Differential accumulation and metabolism. Biochem Pharmacol 57: $1283-1295$.

Roberts BJ, Hamelehle KL, Sebolt JS, Leopold WR. 1986. In vivo and in vitro anticancer activity of the structurally novel and highly potent antibiotic CI-940 and its hydroxy analog (PD 114,721). Cancer Chemother Pharmacol 16: 95-101.

Roth JA. 1999. p53 prognostication: Paradigm or paradox? Clin Cancer Res 5: 3345.

Roth JA, Nguyen D, Lawrence DD, Kemp BL, Carrasco CH, Ferson DZ, Hong WK, Komaki R, Lee JJ, Nesbitt JC, et al. 1996. Retrovirus-mediated wild-type p53 gene transfer to tumors of patients with lung cancer. Nat Med 2: 985-991.

Saddler C, Ouillette P, Kujawski L, Shangary S, Talpaz M, Kaminski M, Erba H, Shedden K, Wang S, Malek SN. 2008. Comprehensive biomarker and genomic analysis identifies p 53 status as the major determinant of response to MDM2 inhibitors in chronic lymphocytic leukemia. Blood 111: 1584-1593.

Sakakura K, Chikamatsu K, Furuya N, Appella E, Whiteside TL, Deleo AB. 2007. Toward the development of multiepitope p53 cancer vaccines: An in vitro assessment of CD8(+) T cell responses to HLA class I-restricted wildtype sequence p53 peptides. Clin Immunol 125: 43-51.

Saller E, Tom E, Brunori M, Otter M, Estreicher A, Mack DH, Iggo R. 1999. Increased apoptosis induction by 121F mutant p53. EMBO J 18: 4424-4437.

Schuetz A, Min J, Antoshenko T, Wang CL, Allali-Hassani A, Dong A, Loppnau P, Vedadi M, Bochkarev A, Sternglanz $\mathrm{R}$, et al. 2007. Structural basis of inhibition of the human NAD +-dependent deacetylase SIRT5 by suramin. Structure 15: $377-389$.

Senzer N, Nemunaitis J, Nemunaitis M, Lamont J, Gore M, Gabra H, Eeles R, Sodha N, Lynch FJ, Zumstein LA, et al. 2007. p53 therapy in a patient with Li-Fraumeni syndrome. Mol Cancer Ther 6: 1478-1482.

Shamanin V, zur Hausen H, Lavergne D, Proby CM, Leigh IM, Neumann C, Hamm H, Goos M, Haustein UF Jung EG, et al. 1996. Human papillomavirus infections in nonmelanoma skin cancers from renal transplant recipients and nonimmunosuppressed patients. J Nat Cancer Inst 88: 802-811.

Shangary S, Qin D, McEachern D, Liu M, Miller RS, Qiu S, Nikolovska-Coleska Z, Ding K, Wang G, Chen J, et al. 2008. Temporal activation of $\mathrm{p} 53$ by a specific MDM2 inhibitor is selectively toxic to tumors and leads to complete tumor growth inhibition. Proc Natl Acad Sci 105: 3933-3938.

Shen J, Vakifahmetoglu H, Stridh H, Zhivotovsky B, Wiman KG. 2008. PRIMA-1MET induces mitochondrial apoptosis through activation of caspase-2. Oncogene 27: 6571-6580.

Shi J, Zheng D. 2009. An update on gene therapy in China. Curr Opin Mol Ther 11: 547-553.

Shimizu H, Burch LR, Smith AJ, Dornan D, Wallace M, Ball KL, Hupp TR. 2002. The conformationally flexible S9S10 linker region in the core domain of p53 contains a novel MDM2 binding site whose mutation increases ubiquitination of p53 in vivo. J Biol Chem 277: 2844628458.

Smart P, Lane EB, Lane DP, Midgley C, Vojtesek B, Lain S. 1999. Effects on normal fibroblasts and neuroblastoma cells of the activation of the p53 response by the nuclear export inhibitor leptomycin B. Oncogene 18: 7378-7386.

Solomon JM, Pasupuleti R, Xu L, McDonagh T, Curtis R, DiStefano PS, Huber LJ. 2006. Inhibition of SIRT1 catalytic activity increases p53 acetylation but does not alter cell survival following DNA damage. Mol Cell Biol 26: $28-38$.

Soucek L, Whitfield J, Martins CP, Finch AJ, Murphy DJ, Sodir NM, Karnezis AN, Swigart LB, Nasi S, Evan GI 2008. Modelling Myc inhibition as a cancer therapy. Nature 455: 679-683.

Speetjens FM, Kuppen PJ, Welters MJ, Essahsah F, Voet van den Brink AM, Lantrua MG, Valentijn AR, Oostendorp J, Fathers LM, Nijman HW, et al. 2009. Induction of p53specific immunity by a $\mathrm{p} 53$ synthetic long peptide vaccine in patients treated for metastatic colorectal cancer. Clin Cancer Res 15: 1086-1095.

Staples OD, Hollick JJ, Campbell J, Higgins M, McCarthy AR, Appleyard V, Murray KE, Baker L, Thompson A, Ronseaux S, et al. 2008. Characterization, chemical optimization and anti-tumor activity of a tubulin poison identified by a p53-based phenotypic screen. Cell Cycle 7: 3417-3427.

Stewart D, Ghosh A, Matlashewski G. 2005. Involvement of nuclear export in human papillomavirus type 18 E6-mediated ubiquitination and degradation of p53. J Virol 79: 8773-8783.

Stommel JM, Marchenko ND, Jimenez GS, Moll UM, Hope TJ, Wahl GM. 1999. A leucine-rich nuclear export signal in the p53 tetramerization domain: Regulation of subcellular localization and p53 activity by NES masking. Embo J 18: $1660-1672$.

Stunkel W, Peh BK, Tan YC, Nayagam VM, Wang X, SaltoTellez M, Ni B, Entzeroth M, Wood J. 2007. Function of the SIRT1 protein deacetylase in cancer. Biotechnol J 2: 1360-1368.

Supiot S, Zhao H, Wiman K, Hill RP, Bristow RG. 2008. PRIMA-1 (met) radiosensitizes prostate cancer cells independent of their MTp53-status. Radiother Oncol 86: 407-411.

Sur S, Pagliarini R, Bunz F, Rago C, Diaz LA Jr, Kinzler KW, Vogelstein B, Papadopoulos N. 2009. A panel of isogenic human cancer cells suggests a therapeutic approach for cancers with inactivated p53. Proc Natl Acad Sci 106: 3964-3969.

Tang Y, Zhao W, Chen Y, Zhao Y, Gu W. 2008. Acetylation is indispensable for p53 activation. Cell 133: 612-626.

Tian G, Liu J, Sui J. 2009. A patient with huge hepatocellular carcinoma who had a complete clinical response to p53 gene combined with chemotherapy and 
transcatheter arterial chemoembolization. Anticancer Drugs 20: 403-407.

Toledo F, Wahl GM. 2007. MDM2 and MDM4: p53 regulators as targets in anticancer therapy. Int J Biochem Cell Biol 39: 1476-1482.

Turner JG, Marchion DC, Dawson JL, Emmons MF, Hazlehurst LA, Washausen P, Sullivan DM. 2009. Human multiple myeloma cells are sensitized to topoisomerase II inhibitors by CRM1 inhibition. Cancer Res 69: 68996905.

Ulasov IV, Tyler MA, Han Y, Glasgow JN, Lesniak MS. 2007. Novel recombinant adenoviral vector that targets the interleukin-13 receptor alpha2 chain permits effective gene transfer to malignant glioma. Hum Gene Ther 18: $118-129$.

Vakhrusheva O, Smolka C, Gajawada P, Kostin S, Boettger T, Kubin T, Braun T, Bober E. 2008. Sirt7 increases stress resistance of cardiomyocytes and prevents apoptosis and inflammatory cardiomyopathy in mice. Circ Res 102: $703-710$.

van der Watt PJ, Maske CP, Hendricks DT, Parker MI, Denny L, Govender D, Birrer MJ, Leaner VD. 2009. The Karyopherin proteins, Crm 1 and Karyopherin betal, are overexpressed in cervical cancer and are critical for cancer cell survival and proliferation. Int J Cancer 124: 1829-1840.

van Leeuwen I, Lain S. 2009. Sirtuins and p53. Adv Cancer Res 102: 171-195.

Vassilev LT. 2004. Small-molecule antagonists of p53MDM2 binding: Research tools and potential therapeutics. Cell Cycle 3: 419-421.

Vassilev LT, Vu BT, Graves B, Carvajal D, Podlaski F, Filipovic Z, Kong N, Kammlott U, Lukacs C, Klein C, et al. 2004. In vivo activation of the p53 pathway by small-molecule antagonists of MDM2. Science 303: 844-848.

Vaziri H, Dessain SK, Ng Eaton E, Imai SI, Frye RA, Pandita TK, Guarente L, Weinberg RA. 2001. hSIR2(SIRT1) functions as an NAD-dependent p53 deacetylase. Cell 107: $149-159$.

Ventura A, Kirsch DG, McLaughlin ME, Tuveson DA, Grimm J, Lintault L, Newman J, Reczek EE, Weissleder R, Jacks T. 2007. Restoration of p53 function leads to tumor regression in vivo. Nature 445: 661-665.

Wang W, Kim SH, El-Deiry WS. 2006. Small-molecule modulators of p53 family signaling and antitumor effects in p53-deficient human colon tumor xenografts. Proc Natl Acad Sci 103: 11003-11008.

Wang T, Lee K, Rehman A, Daoud SS. 2007. PRIMA-1 induces apoptosis by inhibiting JNK signaling but promoting the activation of Bax. Biochem Biophys Res Commun 352: 203-212.

Wang Q, Li M, Wang Y, Zhang Y, Jin S, Xie G, Liu Z, Wang S, Zhang H, Shen L, Ge H. 2008a. RNA interference targeting CML66, a novel tumor antigen, inhibits proliferation, invasion and metastasis of HeLa cells. Cancer Lett 269: $127-138$.

Wang RH, Sengupta K, Li C, Kim HS, Cao L, Xiao C, Kim S, Xu X, Zheng Y, Chilton B, et al. 2008b. Impaired DNA damage response, genome instability, and tumorigenesis in SIRT1 mutant mice. Cancer Cell 14: 312-323.

Wang W, Takimoto R, Rastinejad F, El-Deiry WS. 2003. Stabilization of $\mathrm{p} 53$ by CP-31398 inhibits ubiquitination without altering phosphorylation at serine 15 or 20 or MDM2 binding. Mol Cell Biol 23: 2171-2181.

Wu X, Bayle JH, Olson D, Levine AJ. 1993. The p53-mdm-2 autoregulatory feedback loop. Genes Develop 7: 11261132.

Xirodimas DP, Stephen CW, Lane DP. 2001. Cocompartmentalization of p53 and $\mathrm{Mdm} 2$ is a major determinant for Mdm2-mediated degradation of p53. Exp Cell Res 270: $66-77$.

Xue W, Zender L, Miething C, Dickins RA, Hernando E, Krizhanovsky V, Cordon-Cardo C, Lowe SW. 2007. Senescence and tumor clearance is triggered by p 53 restoration in murine liver carcinomas. Nature 445: 656-660.

Yang J, Ahmed A, Ashcroft M. 2009a. Activation of a unique p53-dependent DNA damage response. Cell Cycle 8: $1630-1632$.

Yang J, Ahmed A, Poon E, Perusinghe N, de Haven Brandon A, Box G, Valenti M, Eccles S, Rouschop K, Wouters B, et al. 2009b. Small-molecule activation of p53 blocks hypoxia-inducible factor lalpha and vascular endothelial growth factor expression in vivo and leads to tumor cell apoptosis in normoxia and hypoxia. Mol Cell Biol 29: 2243-2253.

Yu Y, Sun P, Sun LC, Liu GY, Chen GH, Shang LH, Wu HB, Hu J, Li Y, Mao YL, et al. 2006. Downregulation of MDM2 expression by RNAi inhibits LoVo human colorectal adenocarcinoma cells growth and the treatment of LoVo cells with mdm2siRNA3 enhances the sensitivity to cisplatin. Biochem Biophys Res Commun 339: 71-78.

Zhang Y, Xiong Y. 2001. A p53 amino-terminal nuclear export signal inhibited by DNA damage-induced phosphorylation. Science 292: 1910-1915.

Zhang Y, Lu H. 2009. Signaling to p53: Ribosomal proteins find their way. Cancer Cell 16: 369-377.

Zhang R, Wang H, Agrawal S. 2005. Novel antisense antiMDM2 mixed-backbone oligonucleotides: Proof of principle, in vitro and in vivo activities, and mechanisms. Curr Cancer Drug Targets 5: 43-49.

Zhang Y, Zhang M, Dong H, Yong S, Li X, Olashaw N, Kruk PA, Cheng JQ, Bai W, Chen J, et al. 2008. Deacetylation of cortactin by SIRT1 promotes cell migration. Oncogene 28: $445-460$.

Zhao W, Kruse JP, Tang Y, Jung SY, Qin J, Gu W. 2008. Negative regulation of the deacetylase SIRT1 by DBC1. Nature 451: 587-590. 


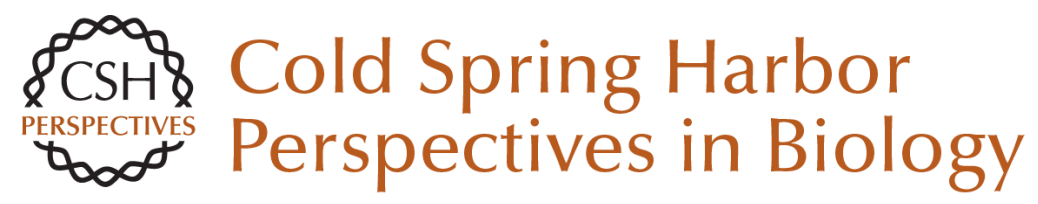

\section{p53-based Cancer Therapy}

David P. Lane, Chit Fang Cheok and Sonia Lain

Cold Spring Harb Perspect Biol 2010; doi: 10.1101/cshperspect.a001222 originally published online May 12, 2010

\section{Subject Collection The p53 Family}

The Origins and Evolution of the p53 Family of Genes

Vladimir A. Belyi, Prashanth Ak, Elke Markert, et al.

Mouse Models of p53 Functions

Guillermina Lozano

TP53 Mutations in Human Cancers: Origins,

Consequences, and Clinical Use

Magali Olivier, Monica Hollstein and Pierre Hainaut

p53 Research: The Past Thirty Years and the Next

Thirty Years

David Lane and Arnold Levine

Transcriptional Regulation by P53

Rachel Beckerman and Carol Prives

p53-based Cancer Therapy

David P. Lane, Chit Fang Cheok and Sonia Lain

Phylogeny and Function of the Invertebrate p53

Superfamily

Rachael Rutkowski, Kay Hofmann and Anton Gartner

Tied Up in Loops: Positive and Negative

Autoregulation of p53

Xin Lu
The Tumor Suppressor p53: From Structures to

Drug Discovery

Andreas C. Joerger and Alan R. Fersht

p53 Regulation of Metabolic Pathways

Eyal Gottlieb and Karen H. Vousden

The Regulation of the p53-mediated Stress

Response by MDM2 and MDM4 Mary Ellen Perry

Zebrafish Models of p53 Functions Narie Y. Storer and Leonard I. Zon

$p 63$ and $p 73$, the Ancestors of p53

V. Dötsch, F. Bernassola, D. Coutandin, et al.

Pathologies Associated with the p53 Response Andrei V. Gudkov and Elena A. Komarova

Single-nucleotide Polymorphisms in the p53

Signaling Pathway

Lukasz F. Grochola, Jorge Zeron-Medina, Sophie Mériaux, et al.

Clinical Outcomes and Correlates of TP53

Mutations and Cancer

Ana I. Robles and Curtis C. Harris

For additional articles in this collection, see http://cshperspectives.cshlp.org/cgi/collection/

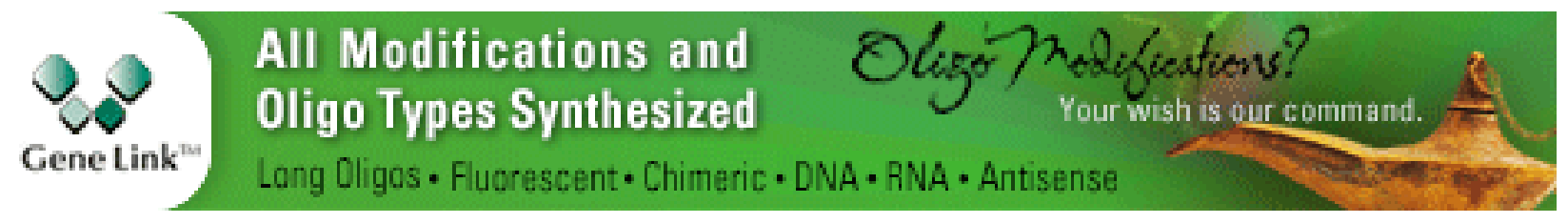

Copyright @ 2010 Cold Spring Harbor Laboratory Press; all rights reserved 